\title{
SURVEYING THE IMPACT OF AUTHENTIC AND PRAGMATIC MARKETING BY PARADIGM SHIFT ON BRAND AUTHENTIC: A CASE STUDY OF SELECTED AZAD UNIVERSITIES (ANZALI, TEHRAN MATKAZ, TONEKABON)
}

\author{
zohreh ali esmaeili \\ Anzali International Unit, Iran \\ E-mail: zohreh_esmaili23@yahoo.com \\ Bahram Kheiry \\ Islamic Azad Universities, Iran \\ E-mail: bahramkheiri@gmail.com
}

Submission: 10/21/2019 Revision: 10/28/2019 Accept: 11/22/2019

\section{ABSTRACT}

The contextual changes of the present age have altered the former order of personal and social relations in such a way that the creation of a new order is accompanied by an epistemic crisis; the crisis of knowledge of new relationships has rendered past valuations inefficient and invalid. In this regard, Katler (1990) considers authenticity as the most influential element in this era of achieving sustainable development and customer Trust, and since the production of university knowledge is the key to sustainable development and today it is faced with quality Issues. This issues, this study aimed to investigate the effect of two marketing, namely authentic marketing and pragmatic marketing through paradigm shifts as a solution to the epistemic crisis of brand authenticity. The research method of this study is based on quantitative and descriptive-survey. The statistical population is Iranian students of Islamic Azad Universities (IAUs) stratified random sampling and sample size based on Morgan table were 385 people. Data were collected and distributed by questionnaire. Structural equation modeling technique with partial least squares approach and SmartPLS2 software were used for data analysis. The findings indicate that both authentic and pragmatic marketing are more effective on brand authenticity through paradigm shift.

Keywords: Authentic marketing, pragmatic marketing, Paradigm shift, Authentic brand 
DOI: 10.14807/ijmp.v11i6.1151

\section{INTRODUCTION}

In 1965, Kotler considered the transaction as a "social exchange" process in a paper that describes the concept of marketing as a social exchange process. Accordingly, the purely economic viewpoint of marketing is a mistake of proximity and it hinders the development of marketing science (HAGIGHI et al., 2013).

Also, in his book entitled the third age of marketing, Katler calls marketing as the era of value creation, and marketing managers, instead of treating people as consumers, regard them as people with the brain, heart, and soul, marketing is not a process that only marketers follow in their relationship with the consumer(KATLER et al., 2010).

Consumers also use marketing in their daily communication. Third-age marketing sees customer as a human being, the human being has four basic elements, a body, a mind that has the ability to think and analyze independently, the heart that can feel the emotions and the spirit or philosophical center of the body, hence he considers authenticity or credibility as the most effective element of the new age in creating sustainable development (KATLER et al., 2010).

In a world full of complexity, customers are looking for companies that meet their deep needs for social, economic, and environmental justice in mission, vision and values. Not only do they seek to meet their functional and emotional needs in the products and services they choose, but also meeting spiritual needs is important for them. Third-age marketing moves the concept of marketing to ideals, values, and spiritualties, and believes that consumers are perfect people and their needs and expectations should not be ignored. Therefore, third-age marketing combines "emotional" marketing with "spiritual" marketing (KOTLER; KARTAJAYA; SETIAWAN, 2010).

In the book Evolution and Evaluation, Jagdish Sheth et al. (2004). explains the evolution of marketing concepts in two aspects of philosophy of science and the universe (2004). Cultural marketing is the second most important marketing element of the third age. Third-age marketing is an approach that does not overlook the concerns and interests of global citizens. Marketers of the third age must understand the problems of the community that are related to their business (KATLER et al., 2010).

The concept of community interest is considered in the new definition of the 2008 American Marketing Association. According to this definition, marketing is a set of activities and processes for establishing communication, supply and exchange of proposals that are valued for consumers, clients, partners and society (KATLER, 2010). 
INDEPENDENT JOURNAL OF MANAGEMENT \& PRODUCTION (IJM\&P)

http://www.ijmp.jor.br

v. 11, n. 6, September - October 2020

ISSN: 2236-269X

DOI: 10.14807/ijmp.v11i6.1151

How can companies create value in their business models? As a response to this fundamental question, Richard Barrett believes companies can look at levels of spirituality in their business models, like humans. He found that human level of spiritual motivation can be considered in the mission, vision and value of companies (BARRETT, 1998).

The warning of Iranian economists to the crisis of value created in Iranian consumer's desire to constantly buy foreign products, which includes types of products from low-level needs to social situations, makes it necessary to redefine and the creation of a new way of producing value in Iranian society (MALJOU, 2017). Various studies on Iranian universities highlight the existence of significant challenges and ambiguities in its brand validity. For example, investigating the attitude of faculty members, (OMRAN, 2006)

Salehi Omran found that one of the most important reasons for faculty members' migration is driving factors such as low income, feeling of discrimination and inequality in society, dissatisfaction resulted from injustice, job insecurity and stressors are the causes of depression (OMRAN, 2006).

In an article entitled Structural Devices of Scientific Development in Iran, Ferasatkhah and Tofighi (2003) explored that If, prior to the Islamic Revolution, the problem with scientific development in Iran was that modernization was followed by a paradigm shift and the adoption of Western-ready patterns and formulas, the Western-style modernization paradigm was at least part of the religious, ideological, and decision-making system of the Islamic Republic after the Revolution, without another valid and efficient paradigm for scientific development is found and is rationally and nationally accepted.

In the realm of paradigms, scientific riddles are made or solved. Cowan says, as long as the service paradigm is sufficient to solve the riddle, but when you can no longer serve and the methods, concepts, metaphysics, tools, norms that constitute the paradigm lose their effectiveness, at this time, scientists are so unhappy with their scientific work that they envy the clowns, as the physicist Koven Wolfgang quotes. It is here that the paradigm is in crisis and the fields of paradigm rotation and the new scientific revolution are formed (FERASATKHAH, 2016).

Given today's customers' need for genuine values and the inefficiencies of existing paradigms to gain customer trust and producing sustainable value, the inefficiency of the paradigm in the Iranian higher education system in producing the original brand of this study examines two originality marketing, first authentic marketing in order to construct and deepen 
DOI: 10.14807/ijmp.v11i6.1151

concepts through dialectics in language based on social platforms and the latter with pragmatic marketing in order to achieve authenticity in practice through the experience of theoretical reason in social or dialectical practice, which is examined by the mediating variable of paradigm shifts (from object-based ontology to phenomenology of existence) to their effect on the original brand.

\section{REVIEW OF LITERATURE}

\subsection{Theoretical background}

According to the Oxford Dictionary, Authentic means " original and without a copy; genuine"(LEEDER, 2019). In marketing, it means the same, it means creating a dialogue between your brand and your audiences that are natural and real. It's not necessarily true or ethical, as many people believe, is a kind of strategy that you can use to build deeper communities based on trust and empathy. Authenticity is essential for a new business (GILMORE; PINE, 2007), which uses the Latin word 'authenticus' and the Greek word 'authentikos' meaning 'acceptability, credibility, trust, not imaginary, false, or imitation, and in accordance with the principle.' (CAPPANNELLI, 2004) This is what you share. The credibility is to believe in your character, writer, or company (PATEL, 2016).

The brand's position alone is not enough. Completion of this process requires a distinction between authenticity for the human soul, which creates a sustainable value in the economy, society and environment, hence it is the only elements that affect third-age of honesty, authenticity, credibility marketing (KATLER, 2010).

A new concept of consumer brand credibility suggests that a credible brand is trustworthy, cares for its consumers, helps them define and build their identity, and represents continuity from the past to the future. (MURHART et al., 2015). Because their credible brands are a meaningful source of identity building, they must have credible behaviors. (BORLAND; FARLEY, 2010).

Valid brands are real, reliable, and meaningful (GILMOURE; PINE, 2007) Credit is increasingly recognized as a desirable brand attribute. Brand originality refers to a brand that is honest and realistic (ALEXANDRE, 2009; GILMOURE; PINE, 2007), distinguishes its credible brand through intimacy, commitment to quality and relevance to its heritage (BORLAND, 2006; NEAPOLI et al., 2014). Valid brands can have the ability to have the ability to communicate with consumers at the emotional level through their quality symbols (ROSSKAA, 2007; MURHART et al., 2015). 
A new concept of credible brand indicates that a credible branding brand for consumers is helping them define and build their identity and represent continuity from the past to the future (RAT et al., 2015. Valid consumption is suitable for a wide range of consumer objects and activities that have the potential to create meaning (BORLAND, 2005). Significant investments have been made in developing brand values and consistently favorable behavior over time (MURHART et al., 2015).

Since valid brands are defined as symbolic resources (BORLAND; FARLEY, 2015) that help consumers define the meaning of their lives (LEE et al., 2006), they benefit from them and have a competitive advantage in terms of building strong relationships with consumer brand (BORLAND, 2006; MURHART et al., 2015), the impact of brand originality on the emotional affiliation of a consumer is different in a variety of situations (MAURARD et al., 2015).

Despite high level of agreement in the correct relationship with consumer behavior and its relation to truth, integrity and transmission of meaning to consumers, literature is characterized by a diverse and divided approach, and the focus of attention is to be considered in an attempt to accept a generally accepted notion. Given this view, Burrland and Farley (2010) spelling issue that the nature of credit in consumption is debatable. "This challenge extends to the field of brand, while there is still a lack of a general definition of credit (Felicitas and Murhart, 2014).

The marketing and consumer research literature acknowledges that attempts to consume credible are due to the loss of traditional sources of meaning and personal identity linked to postmodernity (ARNOLD; PRICE, 2000; BORLAND; FREELY, 2010, THOMSON, 2006). Credibility, as an idea expressed in philosophy and literature, was created in Europe in the 18th century.

But moreover, there were a number of widespread and interwoven developments, all of which were related to modernity, which is a complete expression: the slow recession of belief in the cosmic order with the fixed and undeniable social roles, the idea of coping with the individual's autonomy (with his claim for inner depth, dignity, and self-responsible liberty), the emergence of capitalism, labor, wage and authority of science and enlightenment demand rationality(DAVIS, 2017).

The key point is that these aspects of modernity were prerequisites for stimulating ideal credibility. In other words, this originality was a product and a reaction against modern life. In 
DOI: 10.14807/ijmp.v11i6.1151

this regard, authenticity is like Orthodox religion. Jean-Jacques Rousseau, a philosopher and novelist of the eighteenth century, pointed out each of the original elements: (1) the concept is that we all have a unique and original principle (2) that exists within us (3) must be discovered by ourselves (often in terms of nature), and (4) what we want to express, even in (5) the negation of social agreements (DAVIS, 2017), for example, Halt (2004) ) explained that Adorno "sees the danger of this term in accepting it by those who continue to believe it and experience an imaginary reality that they share through the power of communication."

This interest in "interconnectivity" requires that we, by choosing interpretive methods, understand human behavior. Human science should not be a model of natural science, but should find ways to understand and interpret human communication. These paths must be "Hermeneutics "or" Interpretational "(more like a conversation) (Hossein Gholipour, 2006).

Postmodern society is namely characterized by fragmentation, confusion, emptiness, alienation and by a crisis of morality and identity. Hence, people have become more concerned with identity, meaning and values (COVA, 1999), but also with nostalgia and history (GOULDING, 2000).

By conceiving authenticity as constructed, thus as an experience or as a perception, constructivists overcame some dilemmas based on the assumption that authenticity can be experienced and judged only from the 'outside' - from a historical, cultural distance and with intellectual proficiency (of anthropologists or curators in museums). This discussion is obfuscated by another important question, namely to what authenticity actually pertains (i.e. what can be authentic).

Here Wang (1999) draws a sharp distinction between the authenticity of objects and existential authenticity which can be entirely unrelated with each other. For him, existential authenticity is not object-based but activity-based and can be divided into two dimensions: intra-personal (bodily feelings) and interpersonal (self-making). In a similar vein, Reisinger and Steiner (2006) claim that existential authenticity and object-based authenticity are entirely different concepts and cannot be explored concurrently.

Apart from introducing two basic types of authenticity (i.e. object based and existential), these diverging views also reflect the incommensurability of different epistemological and philosophical positions that have a stake in the conceptualization of authenticity. The 'liberation' of existential authenticity from object and place namely relies on existentialist and phenomenological traditions (OLSEN, 2002). 
DOI: 10.14807/ijmp.v11i6.1151

\subsection{Authentic Marketing}

Authentic marketing is a strategy for organizations to validate their business goals in a credible action, (ACKER, 2014). It seeks to increase brand's desirable characteristics, which requires sustainability of capital resources in developing brand value and extending this behavior over time (MORHART et al., 2015). Because the symbolic source is helping the consumer in his definition and the meaning of his life, so in this strong bond, the brand gains trust and growth (EGGERS et al., 2012).

In this study, authentic marketing will be surveyed in four dimensions: Authentic Marketing Paradigm, Authentic Value, Social Platform Development and Authentic Marketing Mix.

Companies may derive their promise legitimacy from the interests of parties in conversational relations, this is the concept of rhetoric in Heidegger's view (ZACKMAND, 2007).

Because of the interference of the interpretive mentality with the use of dialectics, truth may not be derived from method in philosophical hermeneutics, that is, through questionable answering to the issue at hand (GHARABAGH, 2008).

It is also possible to understand the meaning of interpretive approach through recognition of conceptual approach and phenomenology that are considered as interpretative approaches. The conceptual method of interpretive approach is an attempt to reveal meaning, there is no real starting point for achieving meaning, since each understanding contains the previous understanding (hermeneutic period) (SHIRODI, 2009).

Authentic values are the opposite of Maslow's pyramid. In fact, creative people have a strong belief in the Maslow's reverse pyramid. Spirituality are valuable aspects of immaterial life and enduring realities in creative communities, businesses that respond to their spiritual needs. The future value proposition of marketing is the supply of spirituality. Value-Added Business Modeling is the new infrastructure of third age marketing (KATLER, 2010).

One way for collective value creation appropriate to customer creativity is a business platform. Platforms create value through interaction, they create and shape interaction between external producers and external consumers. An important part of the role of the platform is to create the infrastructure for the formation of interactions and to determine the framework and rules governing these interactions (PARKER; VAN ALLISTON, 2009). 
DOI: 10.14807/ijmp.v11i6.1151

Social media is an online application, platform, or media that facilitates interactions, collaborative work or content sharing (RICHTER; KECH, 2007), interactions with social media fundamentally change the dynamics of brand and customer communication, as well as the motivation for developing user-generated content (UGC) on social media also changes (KAPLAN; HEINLEN, 2010).

Authentic marketing is a type of postmodern marketing that emphasizes the phenomenology of consumer existence. In postmodern marketing, customers pay for the symbolic meaning of the product, so the main marketing mix is product enrichment, price paradox, presence of sales and participation in product promotion. (YOUSEFINIA; FARAHBOD, 2010).

\subsection{Pragmatic Marketing}

The word "pragmatism" in Farsi has been translated into "religion of originality of practice", "practical expediency", "pragmatism", "correction", "expediency" and "scientific aptitude". The word is derived from the Greek root Prassein meaning to do. Pragmatism is a method of solving or evaluating rational problems, as well as a theory of the kinds of identifications we are prone to acquire. Called pragmatism, or principle of action, this school considers the truth to be of practical benefit and, in other words, the meaning that the mind makes to achieve better and more practical results (NEJAD; POURSRASKANROOD, 2010).

Pragmatic marketing is examined in this research with four dimensions: Pragmatics, Problem-Based, Evolutionary Product, Strategic Management and Pragmatic Marketing. "Pragmatic-oriented" has a conceptual footprint: we provide practical and meaningful solutions to the problems that product managers face (FARMAND; PHILLIPS, 1999).

Pragmatic marketing is a product development process, based on experience planning adaptability, re-testing and re-adaptability as long if the final result, both theoretically and practically, has evolved as a better product. The first step in pragmatic marketing is to discover what the customer wants to buy. Pragmatic marketing involves understanding market problems by conducting interviews with customers as well as potential customers to understand their critical issues. This measure is also important to understand why potential customers and clients have evaluated a product in a particular way, and also includes an assessment of the strengths and weaknesses of competition (VAMICHA, 2018).

The strategic management process of pragmatic marketing is a framework, this pragmatic marketing framework improves a standard language for one’s entire product team 
DOI: 10.14807/ijmp.v11i6.1151

and provides an outline of the key activities needed for profitability, problem-oriented products to the market, which includes the following steps: market, focus, business, planning, empowerment and support (NUTINSKY, 2007).

\subsection{Paradigm shift}

The shit paradigm is reminiscent of Thomas Cowan and his famous book The Structure of the Scientific Revolution (COWAN, 2012). Paradigm is the epistemic and social horizon and space that provides the grand parachute rotational pattern. Basic concepts are important in every time paradigm. Every paradigm contains values and norms that tools become important to him and turns to insignificant tools.

The set of these tools, norms, assumptions, concepts, and habits are formed in a cyclical context called the paradigm, as Cowan puts it. The community of researchers and scientists breathe in a paradigm, and their science takes place in the paradigm (FERASATKHAH, 2016). The business paradigm is a set of rules that delineate boundaries and illustrate how to act and solve problems within it.

Inspired by the historiography of science, Jules Arthur Barker proposed a paradigm shift. With the paradigm shifting, the return to the zero point is happening and all competitors have to start the game off. Newcomers can seize opportunities to compete with industry players and win. The decline of Swiss watchmaking and the emergence of Japanese watchmaking is an example of this type of change (BAKKER, 1993; KHALEGHI; POUREZAT, 2011).

The growing trend of consumers working together has impacted businesses. Companies no longer have complete control over their brand because they are competing with the collective power of consumers. This growing consumer trend that restricts marketers' activity is what Vip Forrest has called brand theft (FORREST, 2005). Nowadays companies have to collaborate with their consumers. This starts when marketing managers listen to their consumers to understand their minds. When consumers play a key role in creating value through the co-creation of products and services, more advanced partnerships occur (CUTLER, 2010).

In today's age when word-of-mouth advertising has become a new medium and consumers are more trusted by strangers in their community than corporations, brands without authenticity have no chance of survival. There is also lies and deception on social media, but due to the collective wisdom of consumers, it will quickly be exposed (KATLER, 2010). 


\section{INDEPENDENT JOURNAL OF MANAGEMENT \& PRODUCTION (IJM\&P)}

http://www.ijmp.jor.br

v. 11, n. 6, September - October 2020

ISSN: 2236-269X

DOI: 10.14807/ijmp.v11i6.1151

For over 60 decades, marketing concepts have been vertical. In order to regain trust, a consumer trust system must be designed and implemented. The new system of gaining consumer confidence is horizontal. The time has come for the end of the divide between marketers and consumers (KATLER, 2010). Consumer growth, out-of-structure changes that have limited the ability for consumers to control consumers and the new wave technology has made marketers face the crisis of responding efficiently to new relationships. Accordingly, the present study explores the effect of changing ontology from object-oriented to phenomenology of existence and changing ontology to dialectics in language and practice in the context of sustained customer interaction ( KOLAR; ZABKAR, 2010).

"Creating originality in marketing" is partly seen as a paradox, "all human economic entities are cognitively fraudulent - meaning within themselves without credibility and yet its output can be phenomenologically real, that is, it is perceived as valid by the people who buy it" (GRENOBLE ECOLE, 2015.)

The existential phenomenological paradigm has a contextual (context-centered) perspective in which experiences emerge as a pattern out of context. Ontologically, the experience and the world can be understood as a coherent unit that underlies the burden of social, empirical, and interpersonal issues with the individuals or groups who see it. Epistemologically, it has a subjective negotiating position.

That is, it is assumed that the researcher and the subject are interacting in such a way that the findings are interpolated and interpreted in the course of the research. In this active and passive approach, cognition is one and knowledge is produced and reproduced in an interactive, relational, and contingent process. The knowledge generated in the interaction process has been evaluated and rethought, and as a collaborative product, it has helped to explain and understand the social world of the subjects.

The logic of the research is explanation, interpretation and rethinking, meaning that the researcher seeks to extract and understand the pattern that emerges from the context. It is a holistic research strategy that relates the relevant descriptions of of everyone's experiences to the overall context of the world of life (THOMPSON, 1989; HOSSEINGHOLIPOUR et al., 2014).

The existo and existee verb in Latin means leaving from appearing. The term is also common to being and ontology, but it refers to being aware of a reality in the philosophies of existentialism; in other words, existence refers to the particular way of human existence and from existentialism to the authenticity of existence. Kant's and Habermas's knowledge entails adopting a "dialectical approach" that emphasizes the unity and plurality of rational knowledge. 
DOI: 10.14807/ijmp.v11i6.1151

In Kant's view, any human knowledge, whether theoretical or practical, requires rational justification and a passage of critique.

And he deduced the principles of theoretical and practical reason in a transcendental way from within human experience and cognition. These principles are in fact the general, necessary and prior conditions of any possible experience (HEYDARI, 2014). The new ecology of learning, in the face of its technological and technological practices, reveals profound paradigm shifts that have broad dimensions of thought, communication, behavior, and culture (REDDY; MANGULIKA, 2002; PETERS, 2000).

Previous conventional training has been subject-oriented and cognitive-based, while new paradigms are process-oriented and communication-based. Closed, elitist, and one-way teaching patterns (one-way and vertical transfer of information from professor to student) are transitioning to open, inclusive, two-way, and horizontal interactive patterns of free information exchange. $84.2 \%$ of the respondents perceive corporate culture as a threat to academic authenticity. (FERASATKHAH, 2006).

\section{MODEL}

The conceptual model derived from qualitative research is data-based that overlaps with in-depth interviews with marketing experts and those in other fields (economics, philosophy, sociology, psychology) overlapping concepts, as well as coding and analyzing modern day articles and theories. Research model has been shown in Figure 1.

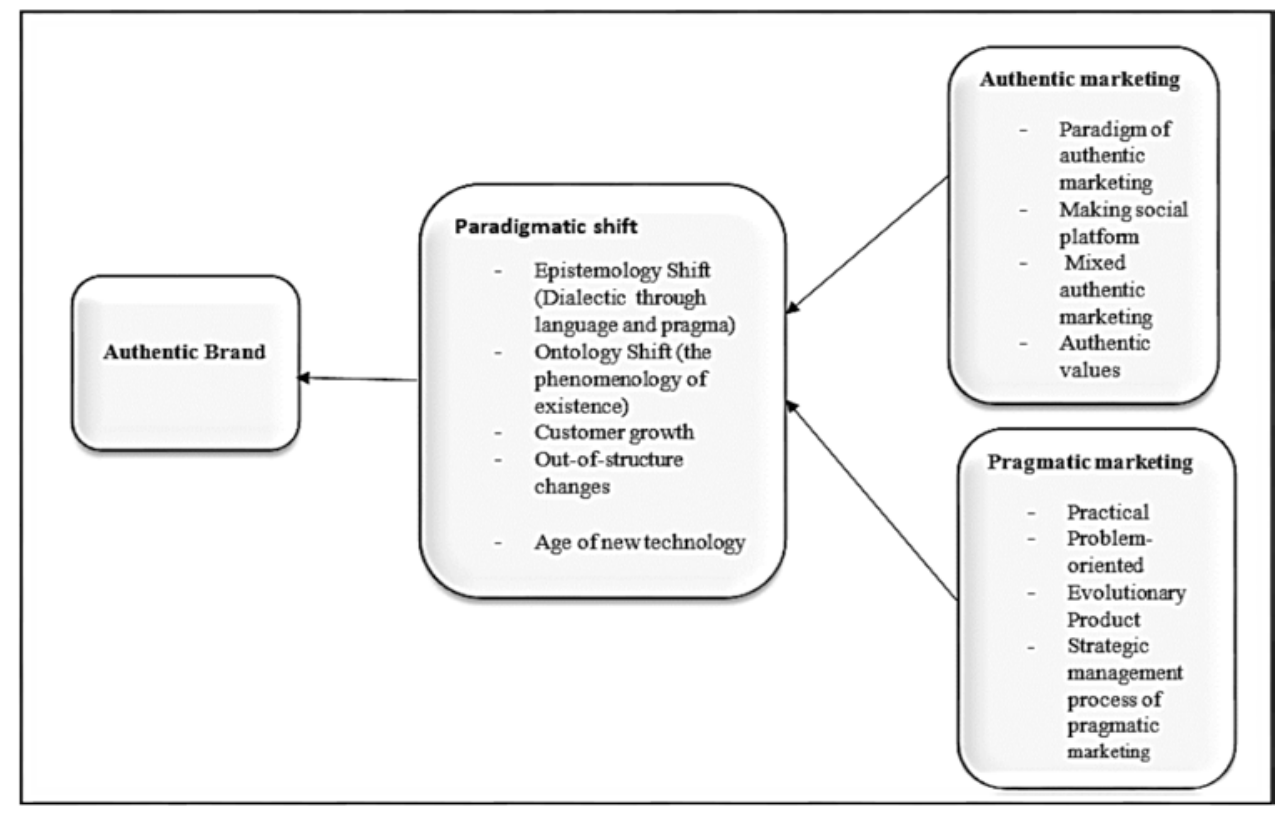

Figure 1: The Authentic and Pragmatic Marketing Process Model Source: Kheiri and Esmaili, (1989) 
DOI: 10.14807/ijmp.v11i6.1151

\section{HYPOTHESES}

There are three views on the concept of objective originality, constructive and existentialist objective perspective refers to authenticity as an objectively measurable quality of an entity that is evaluated by experts (TRILING, 1972). According to the constructivist view, credibility is a prediction of consumer beliefs, expectations, and perspectives on an entity (WANG, 1999), the existentialist perspective considers authenticity as belonging to the self rather than to the external entity (GLOBE, 1995).

Zabkar and Clar (2010) examined it as objective and existentialist approaches. The model of this study considers the effect of two marketing of authenticity, the original marketing being a postmodern marketing and the existentialist perspective of authenticity, and pragmatic marketing which is a pragmatist marketing and takes the objective view of authenticity which deals with language and practice through paradigm shifts to phenomenology of existence with epistemology.

\subsection{Main Hypotheses}

a) Authentic marketing has a significant influence on the paradigm shift.

b) Pragmatic marketing has a significant influence on the paradigm shift.

c) The paradigm shift has a significant influence on the original brand.

d) Original marketing has a significant influence on the original brand with the mediating role of paradigm shift.

e) Pragmatic marketing has a significant influence on the original brand with the mediating role of paradigm shift.

\section{METHODS}

The present study is a quantitative research in terms of approach, in which the researcher collects data with predetermined tools that result in the statistical data, and is of a descriptive type. In descriptive research, the researcher seeks out how and what he wants to know about the phenomenon or variable. In other words, this study examines the status quo and systematically describes its current status, explores its features and traits, and examines the relationship between variables if necessary (HAFEZNIA, 2008). 
DOI: 10.14807/ijmp.v11i6.1151

Since the purpose of this study is to describe the presentation of a native model for authentic marketing and pragmatic marketing and their interaction and contrast, this research is considered as a descriptive study.

Surveying is a way to obtain data about the views, beliefs, opinions, behaviors or characteristics of a group of members of a statistical community through research. More formally, Ross, Wright, and Anderson define surveying as: "Surveying is a set of standardized methods used to gather information about individuals, families, or larger collections. Data is collected by asking people who are regularly selected and grouped into sample groups” (WILCOX et al., 2007).

Therefore, this research is a survey type. In the quantitative section, the descriptivesurvey research method was used to evaluate the described phenomenon. The statistical community can be defined as: all elements and individuals that share one or more attributes on a given geographic scale (global, regional, local, or spatial) (HAFEZNIA, 2014). The statistical population of this study is students of selected Azad universities (Anzali, Tehran center, Tonekabon).

Due to the extent of selected universities, stratified random sampling method was used. In stratified sampling, the units of the study population are grouped into categories that are more homogeneously variable in order to minimize variations within groups. Then, some samples are randomly selected from each class (Hafez NIA, 2009, p. 85).

Thus, the selected free universities were divided into three classes, Anzali, Tehran center, Tonekabon, assuming that the students of the free universities were homogeneous. Then, at each free university, student consensus centers such as corridors, campus and classrooms were selected and the researcher randomly referred to student consensus centers and, after giving a brief explanation of the research topic, were asked to fill out a questionnaire if they were university students. And the sample size calculated 385 people based on Morgan's Table.

Questionnaire was used for data collection. The questionnaire contains Several questions about the variables measured by the study population. These questions are constructed using specific techniques as well as scales so that the desired information can be gathered from the study population or sample (HAFEZNIA, 2007). The questions in this section are also designed based on a 5-point Likert range.

\section{FINDING}


ISSN: $2236-269 X$

DOI: 10.14807/ijmp.v11i6.1151

\subsection{Descriptive statistics}

Descriptive statistics specifies the general characteristics of the population under study and its general characteristics for other researchers. In addition, this knowledge can be used to generalize the results to other communities, or to design future research questions for other communities. The descriptive statistics of the research are described in Table 1 and 2.

Table 1: Frequency distribution by age category

\begin{tabular}{ccc}
\hline Age range & Frequency & Percentage \\
\hline $\mathbf{1 8}$ - 28 years & 337 & 54.5 \\
$\mathbf{2 8}$ - $\mathbf{3 8}$ years & 159 & 25.7 \\
$\mathbf{3 8}$ - 48 years & 102 & 16.5 \\
$\mathbf{4 8}$ years and more & 20 & 3.2 \\
\hline Total & 618 & 100 \\
\hline Table 2: Frequency & Distribution by Education Level \\
\hline Education & Frequency & Percentage \\
\hline Bachelor's degree & 197 & 31.9 \\
Master's degree & 351 & 56.8 \\
Doctorate & 70 & 11.3 \\
\hline Total & 618 & 100 \\
\hline
\end{tabular}

\subsection{External Model (Measurement Model)}

Are the questions for measuring variables properly selected? Confirmatory factor analysis (CFA) is used for this purpose, such that the factor loading of each marker with its construct has a significant $t$ value at 5\% error level, that is to be outside the range of -1.96 and -1.96, and also the factor loading of each marker with its construct is greater than 0.5 , this marker is then accurate enough to measure that structure or latent traits (Nanali \& Bernstein, 1994). For this purpose, confirmatory factor analysis was performed on questionnaire items as described in Tables 3 and 4.

Table 3: Factor loading and significance of questions (first order analysis)

\begin{tabular}{|c|c|c|c|}
\hline \multirow{4}{*}{ Variable } & Question & Factor loading & Significance \\
\hline \multirow{4}{*}{ Authentic marketing } & AA1 & 0.5 & 13.49 \\
\cline { 2 - 4 } & AA2 & 0.54 & 14.92 \\
\cline { 2 - 4 } & AA3 & 0.62 & 17.46 \\
\cline { 2 - 4 } & AB1 & 0.76 & 39.49 \\
\cline { 2 - 4 } & AB3 & 0.51 & 11.94 \\
\cline { 2 - 4 } & AC1 & 0.80 & 45.69 \\
\cline { 2 - 4 } & AC2 & 0.86 & 66.21 \\
\cline { 2 - 4 } & AC3 & 0.85 & 66.48 \\
\cline { 2 - 4 } & AD1 & 0.88 & 93.13 \\
\cline { 2 - 4 } & AD2 & 0.76 & 37.11 \\
\cline { 2 - 4 } & AD3 & 0.73 & 33.22 \\
\hline \multirow{5}{*}{ Pragmatic marketing } & BA1 & 0.66 & 25.38 \\
\cline { 2 - 4 } & BA2 & 0.78 & 45.24 \\
\cline { 2 - 4 } & BB1 & 0.83 & 56.39 \\
\hline
\end{tabular}


DOI: 10.14807/ijmp.v11i6.1151

\begin{tabular}{|c|c|c|c|}
\hline \multirow{5}{*}{} & BB2 & 0.83 & 53.59 \\
\cline { 2 - 4 } & BB3 & 0.84 & 56.25 \\
\cline { 2 - 4 } & BC1 & 0.87 & 40.21 \\
\cline { 2 - 4 } & BC2 & 0.78 & 39.47 \\
\cline { 2 - 4 } & BC3 & 0.61 & 18.39 \\
\cline { 2 - 4 } & BD1 & 0.83 & 56.16 \\
\cline { 2 - 4 } & BD2 & 0.82 & 49.15 \\
\cline { 2 - 4 } & BD3 & 0.85 & 59.72 \\
\hline \multirow{5}{*}{ Paradigm shift } & CA1 & 0.65 & 22.56 \\
\hline & CA2 & 0.58 & 16.89 \\
\cline { 2 - 4 } & CB1 & 0.74 & 31.63 \\
\cline { 2 - 4 } & CB2 & 0.72 & 28.76 \\
\cline { 2 - 4 } & CB3 & 0.72 & 30.01 \\
\cline { 2 - 4 } & CC1 & 0.79 & 51.00 \\
\cline { 2 - 4 } & CC2 & 0.75 & 38.53 \\
\cline { 2 - 4 } & CC3 & 0.76 & 48.10 \\
\cline { 2 - 4 } & CD1 & 0.79 & 47.48 \\
\cline { 2 - 4 } & CD2 & 0.83 & 67.33 \\
\cline { 2 - 4 } & CD3 & 0.76 & 34.55 \\
\hline \multirow{7}{*}{ Original brand } & D1 & 0.89 & 111.84 \\
\cline { 2 - 4 } & D2 & 0.90 & 96.34 \\
\cline { 2 - 4 } & D3 & 0.74 & 28.13 \\
\hline
\end{tabular}

Table 4: Factor loading and significance of questions (second-order analysis)

\begin{tabular}{|c|c|c|c|}
\hline Variable & Question & Factor loading & Significance \\
\hline \multirow{3}{*}{$\begin{array}{c}\text { Authentic marketing } \\
\text { paradigm }\end{array}$} & AA1 & 0.82 & 39.88 \\
\hline & AA2 & 0.84 & 49.95 \\
\hline & AA3 & 0.84 & 40.51 \\
\hline \multirow{3}{*}{ Making social platforms } & $\mathrm{AB} 1$ & 0.81 & 40.22 \\
\hline & $\mathrm{AB} 2$ & 0.73 & 19.68 \\
\hline & AB3 & 0.81 & 37.29 \\
\hline \multirow{3}{*}{ Authentic marketing mix } & AC1 & 0.88 & 80.91 \\
\hline & AC2 & 0.93 & 139.68 \\
\hline & AC3 & 0.87 & 50.75 \\
\hline \multirow{3}{*}{ Authentic values } & AD1 & 0.91 & 113.12 \\
\hline & $\mathrm{AD} 2$ & 0.85 & 49.09 \\
\hline & AD3 & 0.83 & 42.49 \\
\hline \multirow{2}{*}{ Pragmatism } & BA1 & 0.85 & 44.82 \\
\hline & BA2 & 0.92 & 131.40 \\
\hline \multirow{3}{*}{ Problem-oriented } & BB1 & 0.93 & 125.46 \\
\hline & BB2 & 0.91 & 84.94 \\
\hline & BB3 & 0.92 & 104.45 \\
\hline \multirow{3}{*}{ Evolutionary product } & BC1 & 0.89 & 78.74 \\
\hline & BC2 & 0.89 & 68.85 \\
\hline & BC3 & 0.76 & 31.59 \\
\hline \multirow{3}{*}{$\begin{array}{c}\text { The process of strategic } \\
\text { formulation of pragmatic } \\
\text { marketing }\end{array}$} & BD1 & 0.88 & 78.98 \\
\hline & BD2 & 0.92 & 102.04 \\
\hline & BD3 & 0.93 & 108.89 \\
\hline \multirow{2}{*}{ Epistemological change } & CA1 & 0.91 & 89.58 \\
\hline & CA2 & 0.88 & 56.23 \\
\hline \multirow{3}{*}{ Ontological change } & CB1 & 0.88 & 58.40 \\
\hline & CB2 & 0.93 & 100.97 \\
\hline & CB3 & 0.94 & 104.96 \\
\hline Consumer growth & CC1 & 0.86 & 76.88 \\
\hline
\end{tabular}


ISSN: 2236-269X

DOI: 10.14807/ijmp.v11i6.1151

\begin{tabular}{|c|c|c|c|} 
& CC2 & 0.84 & 51.63 \\
\cline { 2 - 4 } & CC3 & 0.90 & 97.78 \\
\hline \multirow{3}{*}{ Out-of-structure changes } & CD1 & 0.83 & 49.37 \\
\cline { 2 - 4 } & CD2 & 0.90 & 118.03 \\
\cline { 2 - 4 } & CD3 & 0.85 & 59.01 \\
\hline
\end{tabular}

The measurement model of the research variables is presented in two levels of significance and standard coefficients in Figures 2, 3, 4, 5.

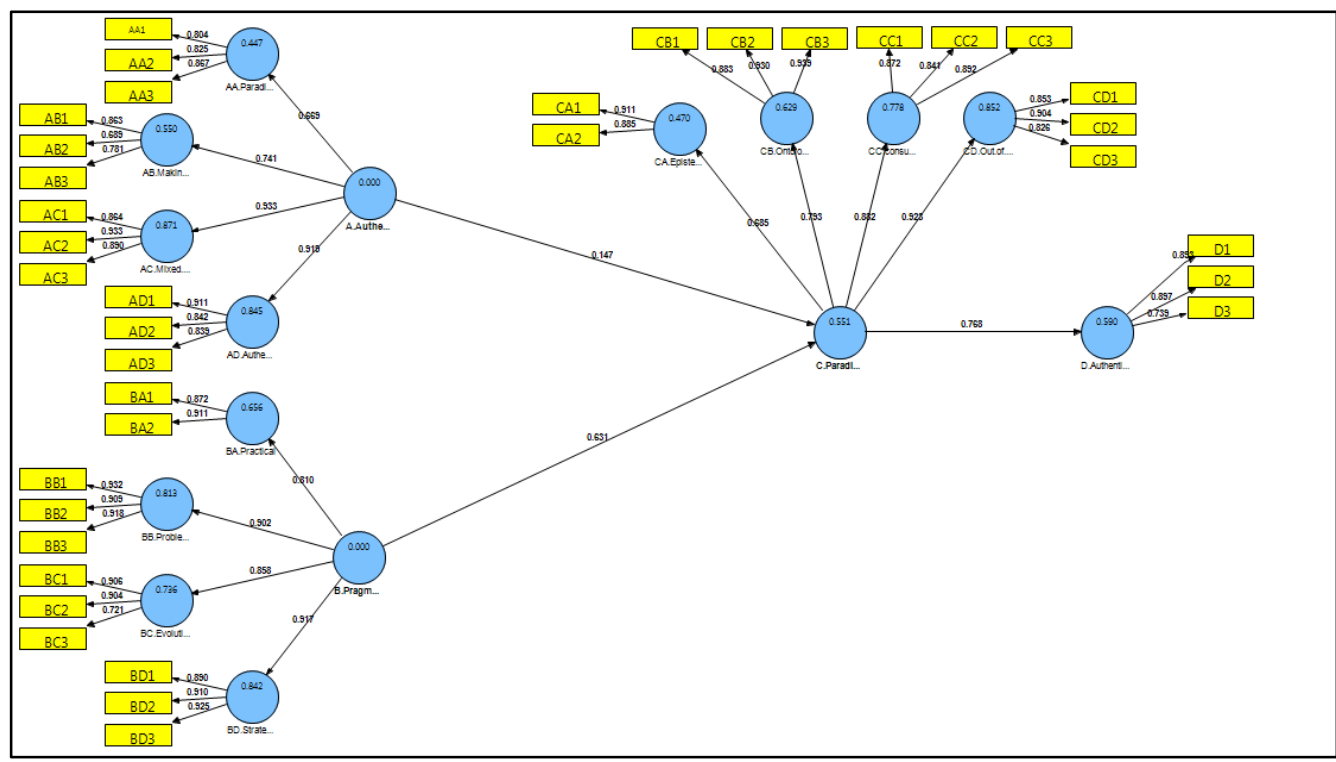

Figure 2: External model of First-order hypothesis in the general standard state

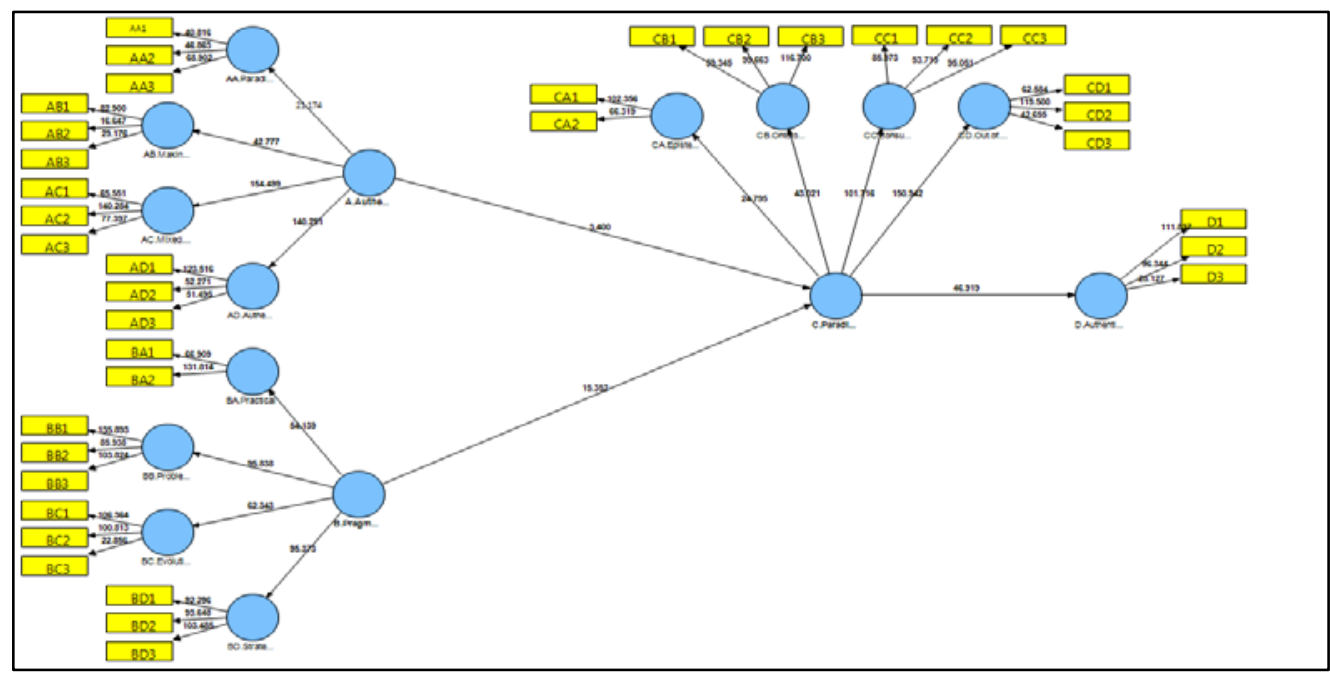

Figure 3: the external model of first-order hypotheses in general significance state 
DOI: 10.14807/ijmp.v11i6.1151

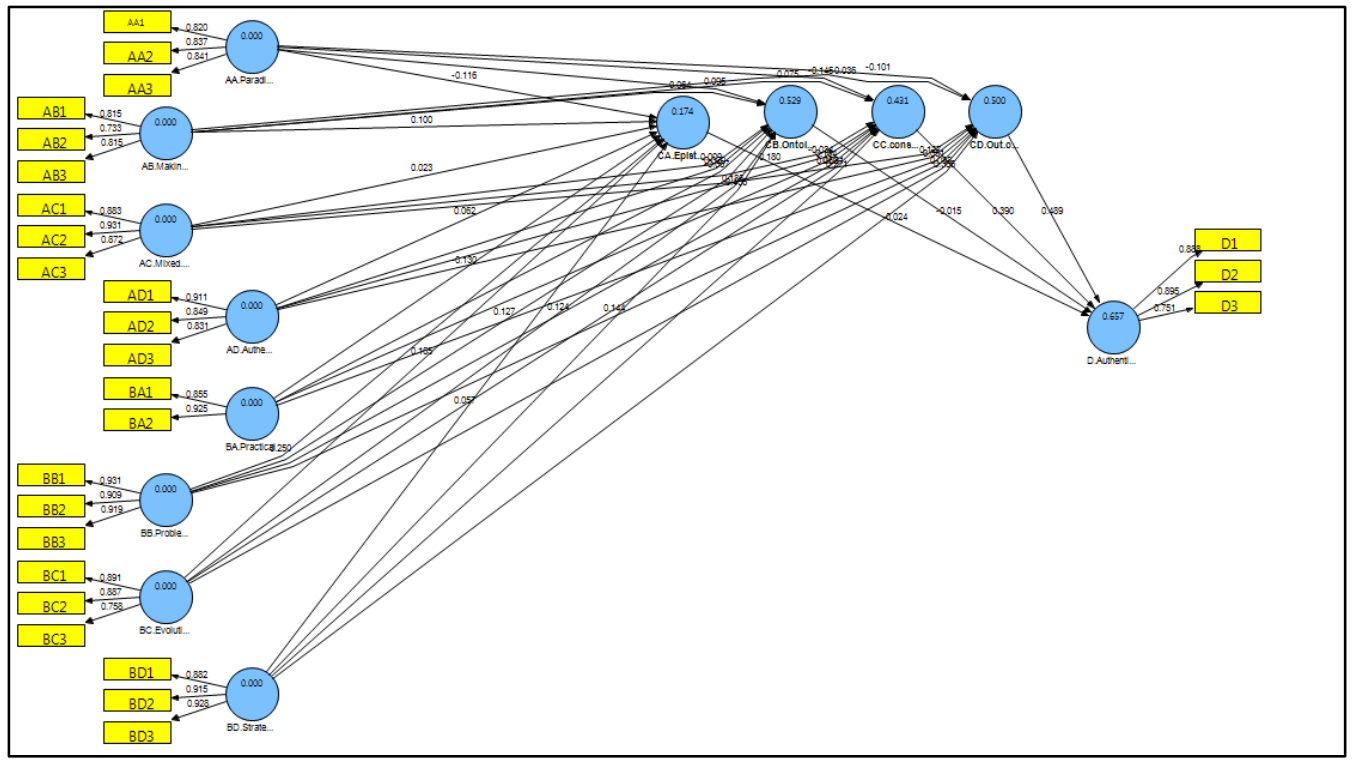

Figure 4: the external model of second-order hypotheses in the general standard state

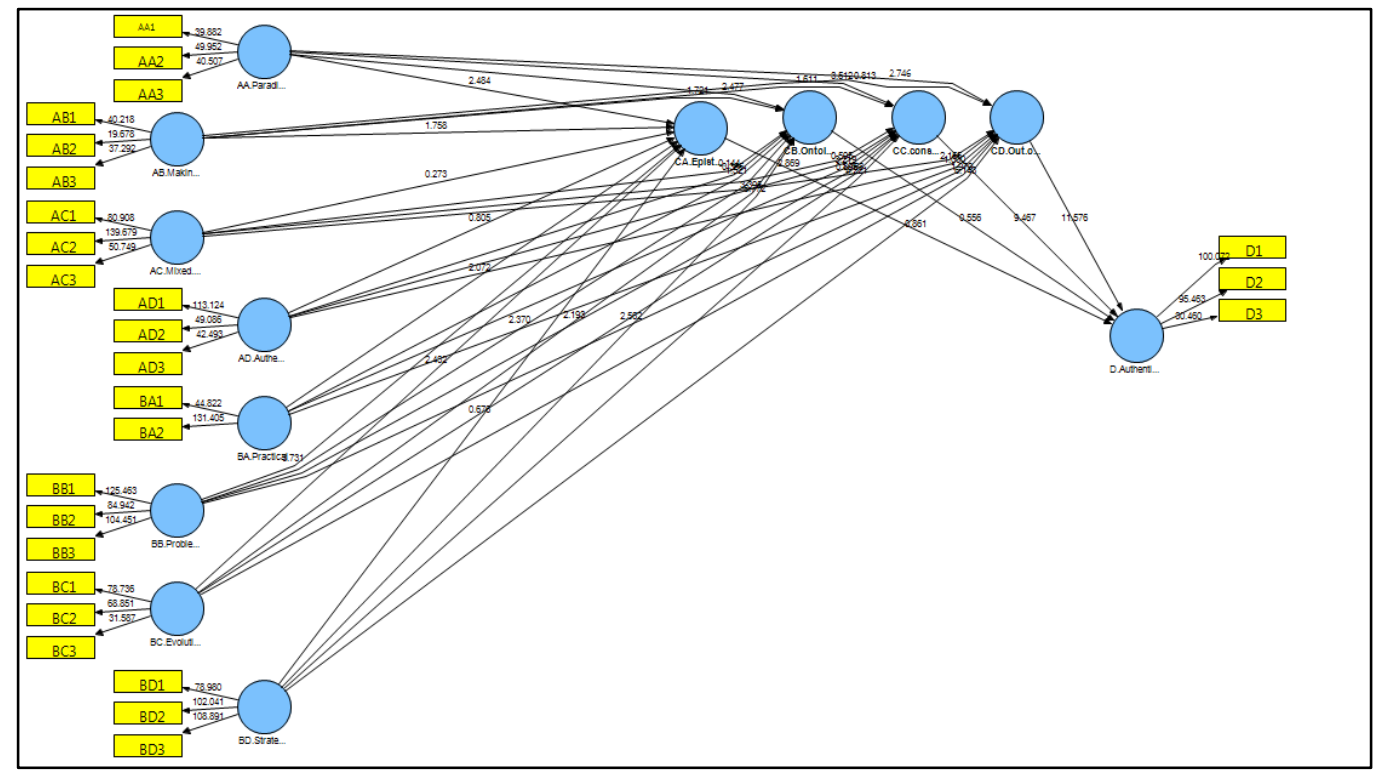

Figure 5: External model of second-order hypotheses in the general significance state

\subsection{Internal model (structural model)}

An intrinsic model (structural model) describes the relationships between latent variables and determines how much of the variance of a latent variable is explained by other latent variables. Regular indices for testing are used to evaluate the model, including R2, path coefficients and critical coefficients. In diagrams 6, 7, 8 and 9 below, the internal model of research for research hypotheses in both standard and significant states can be observed. 
DOI: 10.14807/ijmp.v11i6.1151

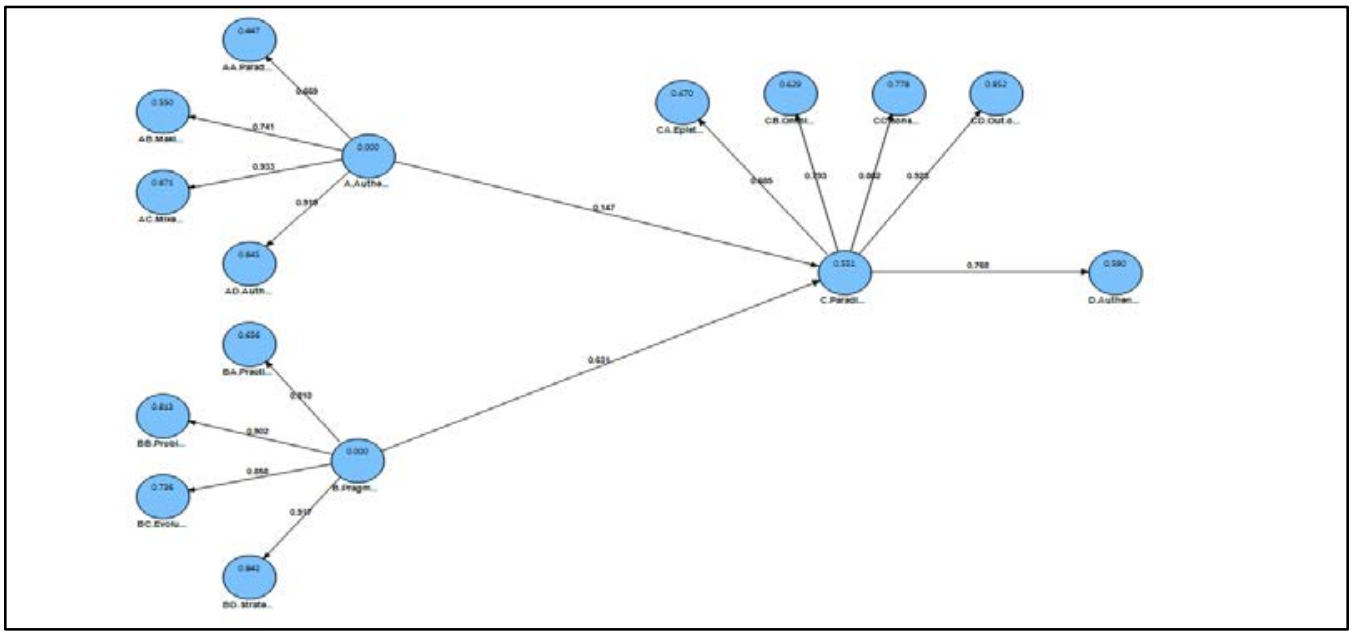

Figure 6: Internal model of first-order hypotheses in the general standard state

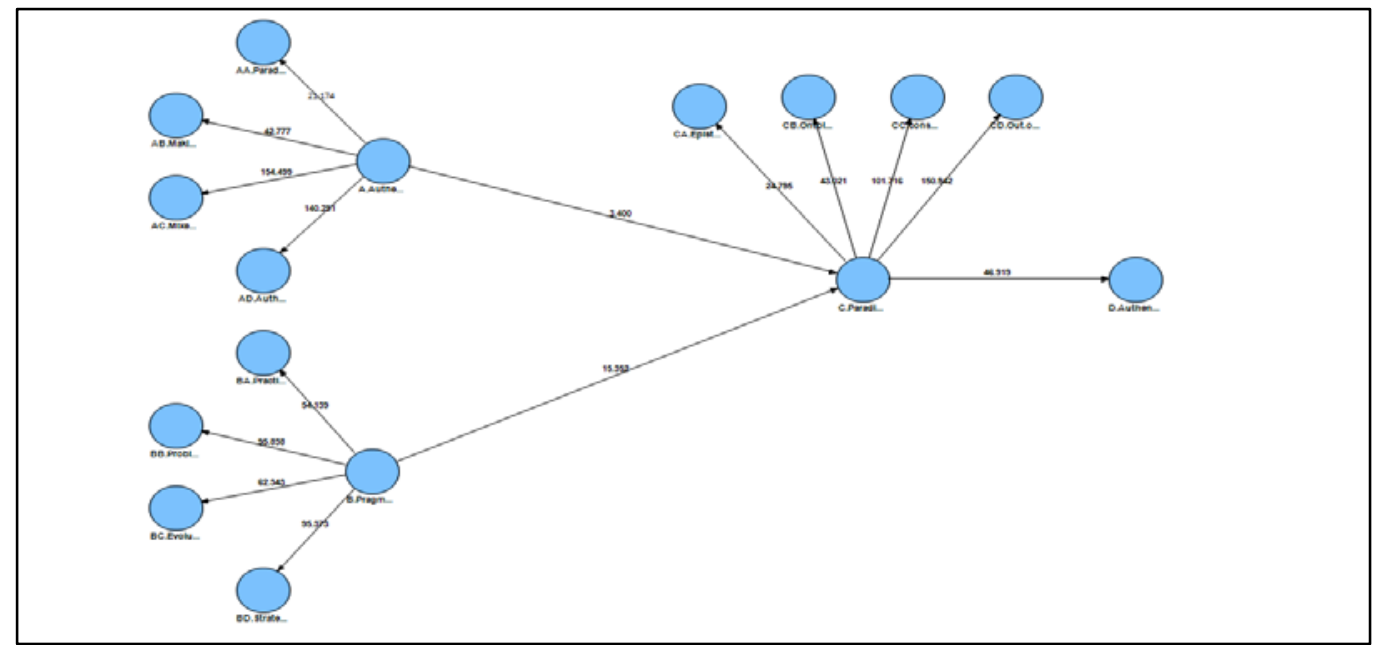

Figure 7: Internal models of first-order assumptions in general significance state

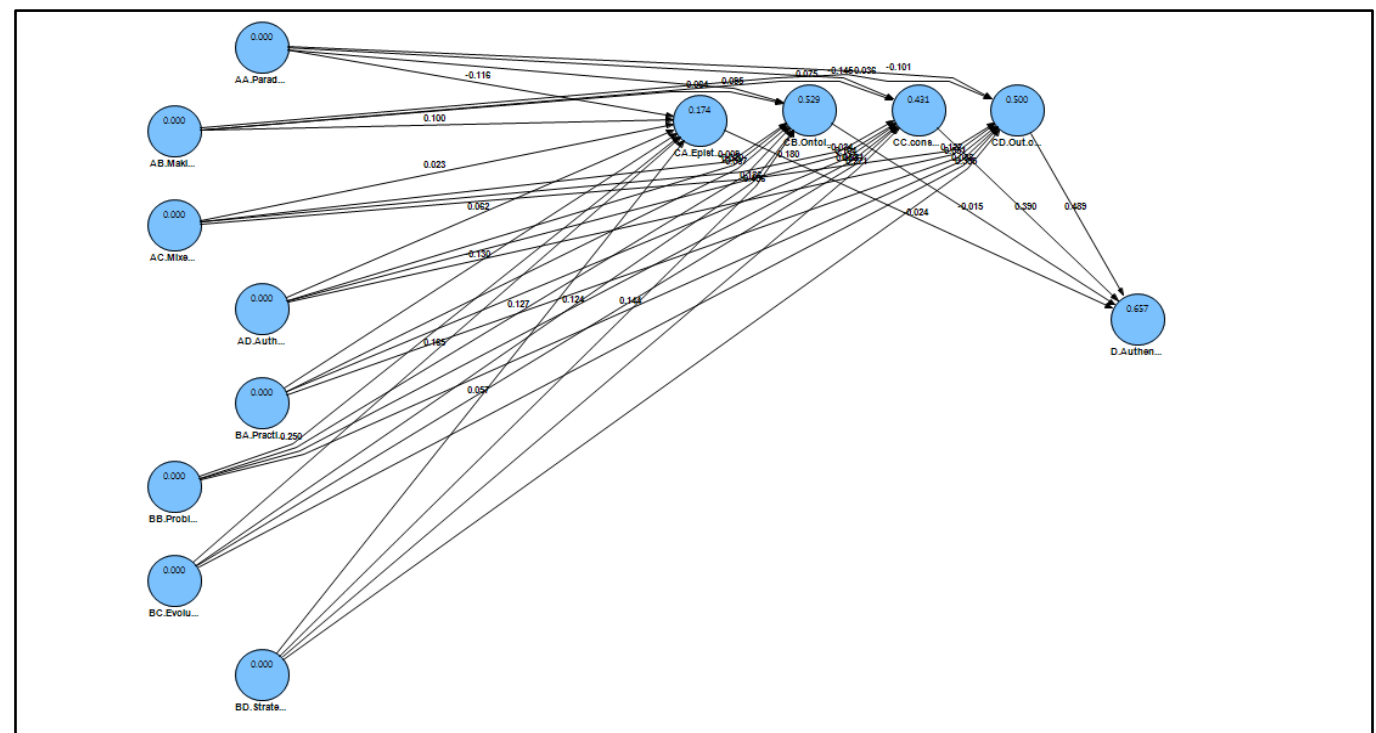

Figure 8: Internal model of second-order hypotheses in the general standard case 
DOI: 10.14807/ijmp.v11i6.1151

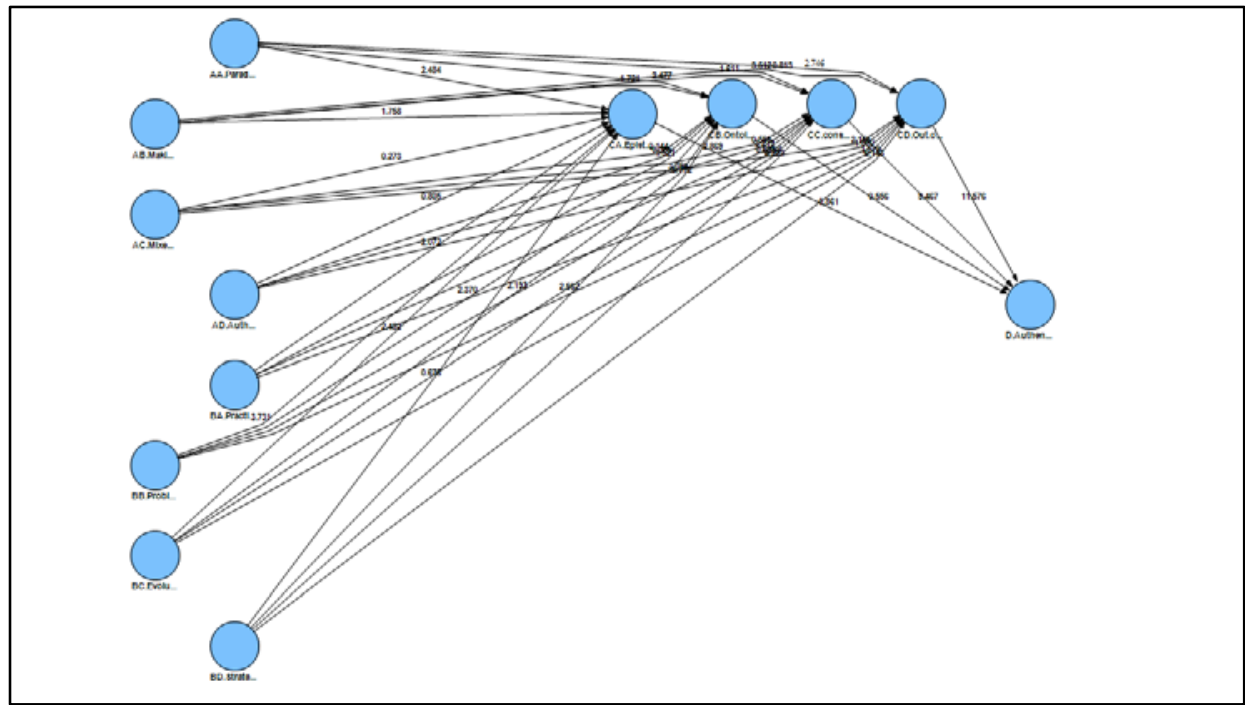

Figure 9: The internal model of second-order hypotheses in the general significance state

R2, or coefficient of determination, indicates the effect that exogenous variables have on an endogenous variable. Chin (1998) identified three values of $0.19,0.33$, and 0.67 as the criterion values for weak, medium, and strong values.

Watzels et al. (2009) identified three values of 0.01, 0.25 and 0.36 as weak, moderate and strong values for GoF. Tables 5 and 6 show the internal fitting of the model.

Table 5: Calculation of internal model fitting (first order analysis)

\begin{tabular}{|c|c|c|}
\hline Variable & Communality & 0.00 \\
\hline Authentic marketing & 0.52 & 0.00 \\
\hline Pragmatic marketing & 0.62 & 0.55 \\
\hline Paradigm shift & 0.55 & 0.59 \\
\hline Original brand & 0.72 & \\
\hline Goodness of fit index & \multicolumn{2}{|c|}{0.59} \\
\hline
\end{tabular}

Table 6: Calculating the fit of the internal model of second-order hypotheses

\begin{tabular}{|c|c|c|}
\hline Variable & Communality & R2 \\
\hline Authentic marketing variable & 0.69 & 0.00 \\
\hline Building social platforms & 0.62 & 0.00 \\
\hline Authentic marketing mix & 0.80 & 0.00 \\
\hline Authentic values & 0.75 & 0.00 \\
\hline Pragmatism & 0.79 & 0.00 \\
\hline Problem-oriented & 0.85 & 0.00 \\
\hline Evolutionary product & 0.72 & 0.00 \\
\hline $\begin{array}{c}\text { The process of strategic } \\
\text { formulation of pragmatic } \\
\text { marketing }\end{array}$ & 0.83 & 0.00 \\
\hline Epistemological change & 0.81 & 0.17 \\
\hline Ontological change & 0.84 & 0.53 \\
\hline Consumer growth & 0.75 & 0.43 \\
\hline Out-of-structure changes & 0.74 & 0.50 \\
\hline Original brand & 0.72 & 0.66 \\
\hline Goodness of fit index & \multicolumn{2}{|l}{} \\
\hline
\end{tabular}


DOI: 10.14807/ijmp.v11i6.1151

As you can be observed, the goodness of fit index for all the hypotheses is in the strong range. That is, the internal model is robust enough to test hypotheses and the test results can be statistically reliable.

\subsection{Testing hypotheses}

Based on the internal model obtained from the research hypothesis test, the validation or rejection of the research hypothesis will be examined. To confirm or reject the hypotheses, a significant coefficient (t-statistic) is used, if the t-statistic is greater than -1.96 or less than 1.96 (at 5\% error level), the hypothesis is confirmed and a significant relationship is obtained between the two hidden variables. The results of the hypothesis analysis are presented in Tables 7 and 8.

Table 7: results of partial least squares analysis for first-order research hypotheses

\begin{tabular}{|c|c|c|c|c|}
\hline $\begin{array}{l}\text { Number of } \\
\text { hypothesis }\end{array}$ & Hypotheses & $\begin{array}{c}\text { Path } \\
\text { coefficients }\end{array}$ & $\begin{array}{c}\text { Significance } \\
\text { value }\end{array}$ & Test result \\
\hline H1 & $\begin{array}{l}\text { Authentic marketing has a } \\
\text { significant effect on the } \\
\text { paradigm shift. }\end{array}$ & 0.15 & 3.40 & Confirmed \\
\hline $\mathrm{H} 2$ & $\begin{array}{l}\text { Pragmatic marketing has a } \\
\text { significant effect on the } \\
\text { paradigm shift. }\end{array}$ & 0.63 & 15.35 & Confirmed \\
\hline H3 & $\begin{array}{l}\text { The paradigm shift has a } \\
\text { significant effect on the original } \\
\text { brand. }\end{array}$ & 0.77 & 46.92 & Confirmed \\
\hline $\mathrm{H} 4$ & $\begin{array}{l}\text { Original marketing has a } \\
\text { significant impact on the } \\
\text { original brand with the } \\
\text { mediating role of paradigm shift. }\end{array}$ & \multicolumn{2}{|c|}{0.11} & Confirmed \\
\hline H5 & $\begin{array}{l}\text { Pragmatic marketing has a } \\
\text { significant impact on the } \\
\text { original brand with the } \\
\text { mediating role of paradigm shift. }\end{array}$ & \multicolumn{2}{|c|}{0.48} & Confirmed \\
\hline
\end{tabular}

\subsubsection{Hypothesis 1: Original marketing has a significant effect on paradigm shift.}

- Ho: Original marketing has no significant effect on paradigm shift.

- H1: Original marketing has a significant effect on the paradigm shift.

The path coefficient of the authentic marketing effect on the paradigm shift is 0.15 and has a t value of 3.40. The $t$ value for this parameter is calculated more than 2.58. Therefore, the null hypothesis is rejected with $99 \%$ confidence. That is, there is a significant relationship between the authentic marketing and the paradigm shift and the authentic marketing is effective on the paradigm shift. Therefore, this research hypothesis is accepted. 
DOI: 10.14807/ijmp.v11i6.1151

The significant impact of authentic marketing on paradigm shifts is consistent with the results of Katler (2010) and Mullard et al. (2015). The relationship between authenticity and spirit or philosophical center of human and he phenomenal of originality are consistent with the existence of the phenomenon, showing that authentic marketing of university is effective on the community through changing paradigm shift and there is a need for original marketing with a new ontology to offer genuine value, create new concepts and enhance the quality of community spirituality.

\subsubsection{Hypothesis 2: Pragmatic marketing has a significant effect on the paradigm shift.}

- H0: Pragmatic marketing has no significant effect on the paradigm shift.

- H1: Pragmatic marketing has a significant impact on the paradigm shift.

The path coefficient of the effect of pragmatic marketing on the paradigm shift is 0.63 and has a $\mathrm{t}$ value of 15.35 . The $\mathrm{t}$ value for this parameter is calculated more than 2.58 . Therefore, the null hypothesis is rejected with $99 \%$ confidence. That is, there is a significant relationship between pragmatic marketing and paradigm shift and pragmatic marketing is effective on the paradigm shift. Therefore, this research hypothesis is accepted.

The Significant effect of pragmatic marketing on the paradigm shifts is consistent with the research results of James (1965), Douglas (1999), Jim Bell and Stephen (1990), Mayhewi et al. (2013) who incorporated the practical attitude of pragmatic marketing to confront the consequences of their beliefs, the problem solving process in the social practice and the reinforcement of science and practice in an interactive approach between university and industry and showed that universities will be able to establish a sustainable interaction between philosophy and practice through a paradigm shift in pragmatic marketing, leading to sustainable resource growth.

\subsubsection{Hypothesis 3: The paradigm shift has a significant effect on the original brand.}

- H0: The paradigm shift has no significant effect on the original brand.

- H1: The paradigm shift has a significant impact on the original brand

The path coefficient of the effect of paradigm shift on the original brand is 0.77 and has a t value of 46.92. The $t$ value for this parameter is calculated more than 2.56 . Therefore, the null hypothesis is rejected with $99 \%$ confidence. That is, there is a significant relationship between the paradigm shift and the original brand and the paradigm shift does not affect the original brand. Therefore, this research hypothesis is accepted. 
DOI: 10.14807/ijmp.v11i6.1151

Significance of paradigm shift's effect on original brand is consistent with research results of Cowan (2012), Ferasatkhah (2015), on the need to change paradigm shift when relationship regulation comes with epistemic crisis and it shows that changing the paradigm shift of the selected universities can add to their brand authenticity and contribute to their sustainable value creation.

\subsubsection{Hypothesis 4: authentic marketing has a significant impact on the original brand with the mediating role of paradigm shift.}

- H0: Original marketing does not have a significant impact on the original brand with the mediating role of paradigm shift.

- H1: Original marketing has a significant impact on the original brand with the mediating role of paradigm shift.

Given the confirmation of the first path, i.e. the effect of original marketing on the paradigm shift, as well as the confirmation of the second path, i.e. the effect of the paradigm shift on the original brand, all paths related to this hypothesis have been confirmed; therefore, the null hypothesis is rejected with 95\% confidence. That is, authentic marketing has a significant impact on the original brand with the mediating role of paradigm shift. Therefore, the paradigm shift variable plays a mediating role here. Moreover, the effect of original marketing with the mediating role of paradigm shift on the original brand is 0.11 .

The significant impact of authentic marketing by shift paradigm on original brand is consistent with the research results of Gharabagh (2005) and Shiroudi (2009) in relation to the phenomenological effect of philosophical hermeneutics on deep understanding of phenomena and their asymmetry in existence, the creation of transcendental concepts based on the lived experience of each person, through hermeneutic understanding of concepts in dialectics based on language. On this basis, the selected universities can change their ontology to the phenomenology of existence and dialectics in the concepts that are effective in shaping their original brand content.

\subsubsection{Hypothesis 5: Pragmatic marketing has a significant impact on the original brand with the mediating role of paradigm shift.}

- H0: Pragmatic marketing does not have a significant impact on the original brand with the mediating role of paradigm shift. 
DOI: 10.14807/ijmp.v11i6.1151

- H1: Pragmatic marketing has a significant impact on the original brand with the mediating role of paradigm shift.

Given the confirmation of the first path, i.e. the impact of pragmatic marketing on the paradigm shift, and the second path confirmation, i.e. the effect of the paradigm shift on the original brand, all paths related to this hypothesis have been confirmed, so the null hypothesis is rejected with $95 \%$ confidence. That is, pragmatic marketing has a significant impact on the original brand with the mediating role of paradigm shift. Therefore, the paradigm shift variable plays a mediating role here.

Therefore, the effect of pragmatic marketing with the mediating role of paradigm shift on the original brand is 0.48 . Significance of pragmatic marketing through paradigm shift of the original brand is consistent with the research results of Heidari (2004), Hatami Nejad and Poursraskanrood (2010), which considers the dialectical and progressive view as a social, everchanging and evolving phenomenon. They have always been negative and replaced by positive, progressive and revolutionary elements.

Universities can recognize the negative practical consequences of the theories and target them to increase the utility of society by shifting the paradigm shift to the phenomenology of existence and the dialectics of science and practice between academia and industry.

Table 8. Partial least squares analysis results for second-order research hypotheses

\begin{tabular}{|c|c|c|c|c|}
\hline $\begin{array}{l}\text { Number of } \\
\text { hypothesis }\end{array}$ & hypotheses & $\begin{array}{c}\text { Path } \\
\text { coefficient }\end{array}$ & $\begin{array}{l}\text { Significance } \\
\text { value }\end{array}$ & Test result \\
\hline H6 & $\begin{array}{l}\text { The authentic marketing paradigm } \\
\text { has an impact on the ontological } \\
\text { change }\end{array}$ & -0.12 & 2.48 & Accepted \\
\hline H7 & $\begin{array}{l}\text { Building social platforms has an } \\
\text { impact on ontological change }\end{array}$ & 0.10 & 1.76 & Rejected \\
\hline H8 & $\begin{array}{l}\text { The original marketing mix has an } \\
\text { impact on the ontological change }\end{array}$ & 0.02 & 0.27 & Rejected \\
\hline H9 & $\begin{array}{l}\text { Authentic values has an effect on } \\
\text { epistemological change }\end{array}$ & 0.06 & 0.80 & Rejected \\
\hline H10 & $\begin{array}{l}\text { Pragmatism has an effect on the } \\
\text { epistemological change }\end{array}$ & -0.13 & 2.07 & Accepted \\
\hline H11 & $\begin{array}{l}\text { Problem-centeredness has on effect } \\
\text { on epistemological change }\end{array}$ & 0.25 & 3.73 & Accepted \\
\hline H12 & $\begin{array}{l}\text { The evolutionary product has an } \\
\text { impact on epistemological change }\end{array}$ & 0.16 & 2.43 & Accepted \\
\hline H13 & $\begin{array}{l}\text { The process of strategic formulation } \\
\text { of pragmatic marketing has an } \\
\text { impact on epistemological change }\end{array}$ & 0.06 & 0.68 & Rejected \\
\hline H14 & $\begin{array}{l}\text { The original marketing paradigm } \\
\text { has an impact on ontology change }\end{array}$ & 0.10 & 2.48 & Accepted \\
\hline H15 & $\begin{array}{l}\text { Building social platforms has an } \\
\text { impact on ontological change }\end{array}$ & 0.06 & 1.72 & Rejected \\
\hline H16 & $\begin{array}{l}\text { The authentic marketing mix has an } \\
\text { impact on ontological change }\end{array}$ & 0.01 & 0.14 & Rejected \\
\hline
\end{tabular}


INDEPENDENT JOURNAL OF MANAGEMENT \& PRODUCTION (IJM\&P)

http://www.ijmp.jor.br

v. 11, n. 6, September - October 2020

ISSN: 2236-269X

DOI: 10.14807/ijmp.v11i6.1151

\begin{tabular}{|c|c|c|c|c|}
\hline H17 & $\begin{array}{l}\text { Authentic values have an impact on } \\
\text { ontological change }\end{array}$ & 0.02 & 0.36 & Rejected \\
\hline H18 & $\begin{array}{l}\text { Pragmatism has an effect on } \\
\text { ontological change }\end{array}$ & -0.07 & 1.52 & Rejected \\
\hline H19 & $\begin{array}{l}\text { Problem-centeredness has an effect } \\
\text { on ontological change }\end{array}$ & 0.13 & 2.37 & Accepted \\
\hline H20 & $\begin{array}{l}\text { The evolutionary product has an } \\
\text { effect on ontological change }\end{array}$ & 0.19 & 3.40 & Accepted \\
\hline H21 & $\begin{array}{l}\text { The process of strategic formulation } \\
\text { of pragmatic marketing has an effect } \\
\text { on ontological change }\end{array}$ & 0.41 & 5.77 & Accepted \\
\hline H22 & $\begin{array}{l}\text { The original marketing paradigm } \\
\text { has an impact on consumer growth }\end{array}$ & -0.14 & 3.51 & Accepted \\
\hline H23 & $\begin{array}{l}\text { Building social platforms has an } \\
\text { impact on consumer growth }\end{array}$ & 0.07 & 1.61 & Rejected \\
\hline H24 & $\begin{array}{l}\text { Authentic marketing mix has an } \\
\text { impact on consumer growth. }\end{array}$ & 0.18 & 2.87 & Accepted \\
\hline H25 & $\begin{array}{l}\text { Authentic values has an effect on } \\
\text { consumer growth }\end{array}$ & -0.03 & 0.59 & Rejected \\
\hline H26 & $\begin{array}{l}\text { Pragmatism has an impact on } \\
\text { consumer growth }\end{array}$ & 0.16 & 3.22 & Accepted \\
\hline H27 & $\begin{array}{l}\text { Problem-centeredness has an impact } \\
\text { on consumer growth }\end{array}$ & 0.12 & 2.19 & Accepted \\
\hline H28 & $\begin{array}{l}\text { The evolutionary product has an } \\
\text { impact on consumer growth }\end{array}$ & 0.08 & 1.76 & Rejected \\
\hline H29 & $\begin{array}{l}\text { The process of strategic formulation } \\
\text { of pragmatic marketing has an } \\
\text { impact on consumer growth }\end{array}$ & 0.27 & 4.22 & Accepted \\
\hline Н30 & $\begin{array}{l}\text { The authentic marketing paradigm } \\
\text { has an effect on out-of-structure } \\
\text { changes. }\end{array}$ & -0.10 & 2.75 & Accepted \\
\hline H31 & $\begin{array}{l}\text { Building social platforms has an } \\
\text { effect on out-of-structure changes. }\end{array}$ & 0.04 & 0.81 & Rejected \\
\hline H32 & $\begin{array}{l}\text { Authentic marketing mix has an } \\
\text { effect on out-of-structure changes. }\end{array}$ & 0.05 & 0.89 & Rejected \\
\hline H33 & $\begin{array}{l}\text { Authentic values has an effect on } \\
\text { out-of-structure changes. }\end{array}$ & 0.13 & 2.15 & Accepted \\
\hline H34 & $\begin{array}{l}\text { Pragmatism has an effect on out-of- } \\
\text { structure changes. }\end{array}$ & 0.05 & 1.00 & Rejected \\
\hline H35 & $\begin{array}{l}\text { Problem-centeredness has an effect } \\
\text { on out-of-structure changes. }\end{array}$ & 0.14 & 2.56 & Accepted \\
\hline H36 & $\begin{array}{l}\text { Evolutionary product has an effect } \\
\text { on out-of-structure changes. }\end{array}$ & 0.09 & 1.98 & Accepted \\
\hline H37 & $\begin{array}{l}\text { The process of strategic formulation } \\
\text { of pragmatic marketing has an effect } \\
\text { on out-of-structure changes. }\end{array}$ & 0.38 & 6.14 & Accepted \\
\hline H38 & $\begin{array}{l}\text { Epistemological change gas an } \\
\text { effect on the original brand. }\end{array}$ & -0.02 & 0.86 & Rejected \\
\hline H39 & $\begin{array}{l}\text { Ontology change has an effect on } \\
\text { the original brand. }\end{array}$ & -0.02 & 0.56 & Rejected \\
\hline $\mathrm{H} 40$ & $\begin{array}{l}\text { Consumer growth has an effect on } \\
\text { the original brand. }\end{array}$ & 0.39 & 9.47 & Accepted \\
\hline H41 & $\begin{array}{l}\text { Out-of-structure changes has an } \\
\text { effect on the original brand. }\end{array}$ & 0.49 & 11.58 & Accepted \\
\hline
\end{tabular}

Commentary: The significance of Hypotheses 6, 14, 22 ‘24, 35, 30 is consistent with

Borland's (2005) and Eckol's (2015) research that the output of authenticity must be 
INDEPENDENT JOURNAL OF MANAGEMENT \& PRODUCTION (IJM\&P)

http://www.ijmp.jor.br

v. 11, n. 6, September - October 2020

ISSN: 2236-269X

DOI: 10.14807/ijmp.v11i6.1151

phenomenologically real and internally valid, and with research findings of (KATLER, 2010), Forth (2005) that consumers no longer want to consume alone and are themselves the creators of new lifestyles, and also with research findings of (KATLER, 2010), Forth (2005) that the creation of their consumers has entered the process of value creation to solve social, cultural and economic problems and are no longer passive and have become innovators seeking the spiritual and cultural world and also with research results of Zahro Marshall's (2004), Davies (2002) and Katler's (2010) as clergy and spirituality as valuable aspects of immaterial life and sustainable realities in creative societies. Accordingly, it is suggested that to validate their brand internally, selected universities can use students' presence and creativity to produce new styles and innovations in solving social, economic, and cultural issues by shifting the paradigm of phenomenology to make their role as a spiritual and cultural institution in society more desirable.

Commentary: Disapproval of Hypotheses 7, 8, 9, 15, 16, 17, 23, 25, 31, 32, 38, 39, with Parker et.al's research. (2018) and Sano (2014) and Dragon's (2012) research that platform is a business. Platforms create value through interaction and new social arrangements that develop concepts over time. It also does not consistent with the research conducted by Yousefinia and Farahbod (2010) that customers pay money for symbolic meanings in the postmodern marketing, indicating that in the study community, building social platforms and making meaningful products does not necessarily have a significant relationship with paradigm shift. In addition, there is no significant relationship between ontology and epistemology on brand originality in this society and further research is needed in these cases.

Significance of hypotheses 10, 11, 12, 19, 20, 21, 26, 27, 29, 37, 36, 35 is consistent with research results obtained by Douglas (1999), Wamicha (2018) that pragmatic marketing seeks to produce an evolutionary product based on social criticism. According to the research results obtained by Poursareskanroud (2001) and Anderson (1999), pragmatic marketing should address the problems of the community and improve the current state of society. It also consistent with Nutenski Pragmatic Marketing Strategic Marketing Planning Form (2007), the Pragmatic Institute (1999). Similarly, selected universities can produce evolutionary products to respond to economic, social, cultural problems by strategically planning pragmatic marketing.

Rejecting the hypotheses 13,18،, 28, 34 does not consistent with the results of Anderson (1999), Zandieh (1996), Pursrascanrod (2010). Pragmatism means theoretical reasoning and suggests that pragmatism does not necessarily have ontological change in the studied 
DOI: 10.14807/ijmp.v11i6.1151

community. And social change as well as evolutionary product has no significant relationship with consumer growth, in which case more research is needed.

The significance of hypotheses 40, 41 with research results of Abdollahian (2003), Haghshenas (1393), Sarokhani (1986), regarding the increase and interference of channels of comprehensiveness in the new technology era that impose conditions of out-of-structure changes on societies. Society faces multiple valuations that disputes credits such as authenticity and disbelief. It also consistent with research results obtained by Capstein (2008) and Zechariah (2009), (KATLER, 2010), in the current age when word of mouth has become a new medium and consumers are more trusted by strangers in their community than corporations. Businessmen without authenticity will have no chance of survival. On this basis, it is recommended that selected universities plan to increase their authenticity based on continuous and sustained interaction with the student in order to gain more existence due to consumer growth in value sharing and increasing conflict of value socialization channels.

\section{CONCLUSIONS}

Since the customer trust in brands has diminished and the validity of the value presented by the brand has been decreased, achieving brand authenticity is essential to producing sustainable value. And given that in the new technology era, vertical communication has transformed marketers and customers into horizontal communications, and that their creators and marketers have been competing with them, engaging more customers in the value chain of the company and adding brand authenticity led the organization to produce sustainable value.

Marketing with phenomenological ontology is a kind of postmodern marketing and its methodology is a combination of structured and semi-structured methods.

On the other hand, by reducing the quality, increasing the orientation of the universities and the degree of community orientation that results in the decrease of the level of culture and the growth of the society, the purpose of this research is to show that in the age of globalization, new generation technology and communication rationality, universities To achieve brand authenticity, what can produce sustainable value requires paradigm shifts in ontology and epistemology in their view of students, and to be phenomenological rather than object and commodity, and seek through sustained interaction With them to gain their inner creativity and experience so that they can generate value and culture in the community have a sustainable growth. 
Elements of paradigm shift, namely consumer growth and out-of-structure changes, affect brand authenticity, so universities can create the atmosphere of emergence and emergence of students' talent and their ongoing engagement with themselves, with industry, society, culture. Until they can Manage the out-of-structure changes and guide it towards social, cultural and spiritual alternatives.

The goal of changing ontological view in university is to avoid considering the customer as an instrument, getting internal experience, creativity and sustained customer interaction are key to sustainable knowledge development. Sustainable value production is not separate from economic growth, but it sustains growth, and this paradigm shift, while developing the knowledge economy, affects the quality of university-produced product, making it a prominent and authentic cultural institution, because brand originality has content in social interaction.

\section{REFERENCES}

ABAZARI, Y.; SHARIATI, S.; FARAJI, M. (2011) The Transcendence of Civilization or the Process of Civilizations?. A Reading of culture-civilization problematic. Quarterly Journal of Cultural Research, v. 4, n. 2, p. 19.

AKBARI, M. H. (2006) Democracy and Civil Society. Journal of Social Sciences, n. 7.

ANDERSON, D. R. (1999) Business ethics and the pragmatic attitude. A Companion to Business Ethics Edited by Robert E. Frederick, Blackwell: Publishers Ltd.

ARANI, A. A.; NAJMEH, Z. M.; FATEMEH, M. A. (2016) Comparative Study of Critical Education from the Viewpoint of Girou and Habermas. Journal of Axiology in Education, n. 1.

ARNOULD, E. J.; PRICE, L. L. (2000) Authenticating acts and authoritative performances. Questing for self and community. In RATNESHWAR, S.; MICK, D. G.; HUFFMAN, C. (Eds.), the why of consumption.

ASGARI, D. (2013) The issue of value creation for customer, Bank Ayandeh Bulletin, n. 2. BARRETT-LENNARD, G. T. (1998) Carl Rogers' helping system: Journey and substance. London: Sage.

BEVERLAND, M. B.; LINDGREEN, A.; VINK, M. W. (2008) Projecting Authenticity through Advertising - Consumer Judgments of Advertisers' Claims, Journal of Advertising, v. 37, n. 1, p. 5-15.

BEVERLAND, M. B.; FARRELLY, F. J. (2010) The quest for authenticity in consumption: Consumers'purposive choice of authentic cues to shape experienced outcomes. Journal of Consumer Research, v. 36, n. 5, p. 838-850.

BEVERLAND, M. B.; LINDGREEN, A.; VINK, M. W. (2008) Projecting authenticity through advertising. Journal of Advertising, v. 37, n. 1, p. 5-15.

BELL J, BROWN S. (1990) Pragmatic Perspectives in International Marketing Education. Journal of Management Development, v. 9, n. 1, p. 39-50 
BOUTANG, Y. (2011) Cognitive Capitalism. Business \& Economics - 240 pages. Contemporary perspectives on consumer motives, goals and desires (p. 140-163) London: Routledge.

CAPPANNELLI, G. (2004) Authenticity: Simple Strategies for Greater Meaning and Purpose at Work and at Home. Clerisy Press, Emmis Books.

DAVIS, J. L. (2017) Accomplishing authenticity in a labor-exposing space. Elsevier Ltd. All rights reserved.

DRAGON, R. (2012) Social marketing improve your social media processes and get your customer to stay forever, eBook.

EGGERS, F.; O`DWYER, M.; KRAUS, S.; VALLASTER, C.; GÜLDENBERG, S. (2013) The impact of brand authenticity on brand trust and SME growth: A CEO perspective, Journal of World Business, v. 48, n. 3, p. 340-348.

EMERSON, R. W. (2007) The Letters of Ralph Waldo Emerson. Ed. Ralph L, Rusk, vs. 1_6 and Eleanor M. Tilden, v.s 7_10. New York and London: Columbia University Press.

ESFAHANI, A.; SAEED, H. N.; ARASH, N. A. M. (2012) BUSINESS ETHICS: THE INEVITABLE NEEDS OF TRADE ORGANIZATIONS, Opportunity Quarterly, n. 2.

FARHANGI, A. A.; KARROUBI, M.; SADEGH V. F. (2015) classic data-based theory, description of stages of theory of center gravity identity.

FROSH, P. (2001) To thine own self be true: The discourse of authenticity in mass cultural production. The Communication Review, v. 4, p. 541-557.

FADHILA D. (2018) Authenticity and Transparency in Influencer Instagram Content in Indonesia. Bachelor's Thesis, International Business.

FLORIDA, R. (2005) The Flight of the Creative Class: The New Global Competition for Talent . New York: HarpermBusiness.

GILMORE, J. H.; PINE, B. J. (2007) Authenticity: What consumers really want?. Boston: Harvard Business School Press.

GRAYSON, K.; SCHULMAN, D. (2000) Indexicality and the verification function of irreplaceable possessions: A semiotic analysis. Journal of Consumer Research, v. 27, p. 1730.

GROHMANN, B. (2009) Gender dimensions of brand personality. Journal of Marketing Research, v. 46, n. 1, p. 105-119.

GUEVREMON, A.; GROHMANN, B. (2016) The brand authenticity effect: situational and individual-level moderators. European Journal of Marketing, v. 50, n. 3/4.

GHOLIPOUR, H. (2007) From Weber to Habermas about Science and Values. Robert Hollinger, Humanities Psychology Magazine, n. 48.

HABERMAS, J. (1987) The Theory of Communicative Action. Translated by T. McCarthy. Boston: Beacon Press. v. 1 and 2.

HAGHIGHI, M. K. M.; ELIYA, B. Z. (2013) Customer's Trust to Large Store Personnel: A study in chain store clients. Study in Chain stores in Shahrvand Tehran, Management Sciences Association, v. 8, n. 3. 
HAKIMI, M. (1984) Compilation and editing by Mahmoud Hakimi. Subject: History; Quotes. Ghalam Publishing, Tehran, 1984. Iran Health Branding. Commercial Management Quarterly, v. 7, n. 1, p. 145-162.

HANDY, C. (1994) The age of Paradox. Boston: Harvard Business school business School Press.

HANDLER, R.; SAXTON W. (1988) Dyssimulation: Reflexivity, narrative, and the quest for authenticity in -living history. Cultural Anthropology, v. 3, n. 3, p. 242-260.

HANNES, K.; STAES, F.; GOEDHUYS, J.; AERTGEERTS, B. (2009) Obstacles to the implementation of evidence-based physiotherapy in practice: a focus group-based study in Belgium (Flanders) Physiotherapy: Theory and Practice, v. 25, n. 7, p. 476-488.

HATAMINEZHAD, H.; AKBARPOUR, S. M. (2011) Pragmatism. Journal of Geographic Information, n. 79.

HE, M.; LI, J.; SHAO, B.; QIN, T.; REN, CH. (2013) Transforming massive data to pragmatic target marketing practice. IBM Research - China.

HEIDARI, H. H. (2004) Habermas in the battle with modern epistemic crisis, communicative rationality instead of instrumental rationality. Institute for Humanities and Cultural Studies, n. 33.

HOLLINGER, R. (2006) From Weber to Habermas about Science and Values. Translated by Gholipour, Hussein, Tehran, Social Sciences: Methodology of Humanities, n. 48 (ISC)

HOLT, D. B. (2002) Why Do Brands Cause Trouble?. A Dialectical Theory of Consumer Culture and Branding, Journal of Consumer Research, v. 29, n. 1, p. 70-90.

HOLT, D. B. (2004) How brands become icons: The principles of cultural branding. Boston: Harvard Business School Press.

HUNT, S. D. (2013) The Basics of Theorizing in Marketing. Mohammad Haghighi and Masoud Karami, Tehran, Krtab Mehraban Publishing Institute.

ILICIC, J. M.; WEBSTER, C. (2014) Eclipsing: When Celebrities Overshadow the Brand, psychology marketing, p. 1040-1050.

INGLEHART, R.; NORRIS PIPPA, N. (1999) Rising Tide: Gender Equality and Cultural Change around the World. Cambridge: CambridgeUniversity Press.

JEANNERAT, H. (2013) Staging experience, valuing authenticity: Towards a market perspective on territorial development, Published in European Urban and Regional Studies, v. 20, n. 4, p. 370-384.

KATLER, F. (2015) Third Generation Marketing. Translated by Hormoz Mehran and Behzad Shahrabi, Reza, Cultural Services Institute Publishing.

KHAKI, G. R. (2011) Research Method with a Thesis Approach. Tehran: Baztab Publication.

KOLAR, T.; ZABKAR,V. (2010) A consumer-based model of authenticity: An oxymoron or the foundation of cultural heritage marketing?, Tourism Management, v. 31, p. 652-664.

KOTLER, P.; KARTAJAYA, H.; SETIAWAN, I. (2010) Marketing 3.0: From Products to Customers to the Human Spirit. Publisher, John Wiley \& Sons. 
LEIGH, T. W.; PETERS, C.; SHELTON, J. (2006) The consumer quest for authenticity: the multiplicity of meanings within the MG subculture of consumption. Journal of the Academy of Marketing Science, v. 34, n. 4, p. 481-493.

MAHJOO, M. (1986) Perspective of the Iranian Economy. Iran Steel news station.

MAHBOUBI M. H. (2015) Value-based sociology by relying on order and security. Tehran, Military science university, Second Edition.

MOHAMMADPOUR, A. (2013) Qualitative Research Method for Handling 1. Tehran: Jameeshenasan Publications.

MANOUCHEHRI, A. (2007) Approach and Methods in Political Science. Tehran, SAMT Publications.

MIRJALILI, S. H. (2002) The Study of the Economic, Political, Social and Cultural Structure. Research Institute for Humanities and Cultural Studies, n. 270.

MORHART, F.; MALAR, L.; GUEVREMONT, A.; GIRARDIN, F.; GROHMANN, B. (2015) Brand authenticity: An integrative framework and measurement scale, Journal of Consumer Psychology, v. 25, n. 2, p. 200-218.

MOULARD, J.; GARRITY, C.; RICE, D. (2015) What Makes a Human Brand Authentic? Identifying the Antecedents of Celebrity Authenticity. Psychology and Marketing, v. 32, n. 2, p. 173-186.

MOULAERT, F.; SEKIA, F. (2003) Territorial innovation models: a critical survey. Regional Studies, v. 37, p. 289-302.

NAPOLI, J.; DICKINSON, S. J.; BEVERLAND, M. B.; FARRELLY, F. (2014) Measuring consumerbased brand authenticity. Journal of Business Research, v. 67, n. 6, p. 1090-1098.

OXFORD ENGLISH DICTIONARY (2019) Prepared by Leeder, K. Oxford, UK: Oxford University Press.

PEIRCE, C. S. (1893) Collected Papers of Charles Sanders Peirce, v. V and VI. Edited by C. Hartshorne and P. Weiss. Cambridge: Harvard University Press.

RAHMANASRHSHT, H. (2007) Organization and Management Theories: From

Modernity to Renaissance Postures, v. II post-modernism era, Tehran, Douran Publishing.

RORTY, R. (1996) Fraternity: The case for a society based not on rights but on unselfishness. New York Times Magazine, p. 155-8.

ROTFELD, H. J. (2014) The pragmatic importance of theory for marketing practice. Journal of Consumer Marketing, v. 31, n. 4 p. $322-327$.

SCHMIDT, S.; HENNIGS, N.; ALBERTSEN, L.; KARAMPOURNIOTI, E.; ROTHENSEE, M. A. (2017) The Dual Information Processing Effect of Pragmatic and Hedonic User Experience on Brand.

SHETH, J. N.; SISODIA, R. S. (2006) Does Marketing Need Reform? Fresh Perspectives on the Future. USA, M.E. Sharpe Inc.

SHIROUDI, M. (2009) The study and methodology of political science. Journal of Religion and Politics, n. 19-20. work and at Home, Clerisy Press, Emmis Books.

TAVASOLI, G. A.; MOUSAVI, M. (2005) The concept of capital in new and classical theories with an emphasis on social capital theories. Journal of Social Sciences, n. 26. 
ISSN: 2236-269X

DOI: 10.14807/ijmp.v11i6.1151

THOMPSON, C. J. (1997) Interpreting Consumers: A Hermeneutical Framework for Deriving Marketing Insights from the Texts of Consumers' Consumption Stories. Journal of Marketing Research, v. 34, p. 438-5.

\section{WHITE, T, J. (1990) Amplification and direct sequencing of fungal ribosomal RNA}

Genes for phylogenetics, Publisher: Academic Press, p.315-322.

\section{ZADEH, F. H.; JAMAL, A. (2013) Proposal writing in Qualitative and Combined}

Studies, Tehran: Jameshenasan Publishing.

ZOHAR, D.; MARSHALL, I. (2004) Spiritual Capital: Wealth We Can Live By: (San Francisco: Barrett_Koehler Publisher.

ZICKMUND, S. (2007) Deliberation, phronesis and authenticity: Heidegger's early conception of rhetoric. Philosophy \& Rhetoric, v. 40, n. 4, p. 406-415.

\section{APPENDIX}

\begin{tabular}{|l|r|r|r|r|}
\hline & $\mathrm{N}$ & \multicolumn{1}{c|}{ Mean } & Std. Deviation & Variance \\
\hline A.Authentic.marketing & 618 & $3 / 1874$ & $0 / 71161$ & $0 / 506$ \\
B.Pragmatic.marketing & 618 & $3 / 2292$ & $0 / 77005$ & $0 / 593$ \\
C.Paradigmatic.shift & 618 & $3 / 259$ & $0 / 79428$ & $0 / 631$ \\
D.Authentic.Brand & 618 & $2 / 5129$ & $0 / 98882$ & $0 / 978$ \\
AA.Paradigm.of.authentic.marketing & 618 & $3 / 4806$ & $0 / 81212$ & $0 / 66$ \\
AB.Making.social.platforms & 618 & $3 / 2697$ & $0 / 77919$ & $0 / 607$ \\
AC.Mixed.authentic.marketing & 618 & $2 / 9337$ & $0 / 94439$ & $0 / 892$ \\
AD.Authentic.values & 618 & $3 / 0658$ & $0 / 94642$ & $0 / 896$ \\
BA.Practical & 618 & $2 / 8172$ & $0 / 93668$ & $0 / 877$ \\
BB.Problem.oriented & 618 & $3 / 1958$ & $0 / 90318$ & $0 / 816$ \\
BC.Evolutionary.Product & 618 & $3 / 507$ & $0 / 80116$ & $0 / 642$ \\
BD.Strategic.management.process.of.pragmatic.marketing & 618 & $3 / 397$ & $0 / 89232$ & $0 / 796$ \\
CA.Epistemology.shift & 618 & $3 / 5469$ & $0 / 99483$ & $0 / 99$ \\
CB.Ontology.shift & 618 & $3 / 7665$ & $0 / 82348$ & $0 / 678$ \\
CC.consumer.Growth & 618 & $2 / 7044$ & $1 / 01404$ & $1 / 028$ \\
CD.Out.of.structure.changes & 618 & $3 / 0183$ & $1 / 00262$ & $1 / 005$ \\
Valid N (listwise) & 618 & & & \\
\hline
\end{tabular}

\begin{tabular}{|c|c|c|c|c|c|}
\hline & $\mathrm{N}$ & \multicolumn{2}{|c|}{ Skewness } & \multicolumn{2}{|c|}{ Kurtosis } \\
\hline & Statistic & Statistic & $\begin{array}{l}\text { Std. } \\
\text { Error }\end{array}$ & Statistic & $\begin{array}{l}\text { Std. } \\
\text { Error }\end{array}$ \\
\hline A.Authentic.marketing & 618 & $0 / 01$ & $0 / 098$ & $-0 / 308$ & $0 / 196$ \\
\hline B.Pragmatic.marketing & 618 & $-0 / 319$ & 0/098 & $0 / 146$ & $0 / 196$ \\
\hline C.Paradigmatic.shift & 618 & $-0 / 296$ & 0/098 & $-0 / 019$ & $0 / 196$ \\
\hline D.Authentic.Brand & 618 & $0 / 331$ & 0/098 & $-0 / 393$ & $0 / 196$ \\
\hline AA.Paradigm.of.authentic.marketing & 618 & $-0 / 376$ & 0/098 & $-0 / 282$ & $0 / 196$ \\
\hline AB.Making.social.platforms & 618 & $-0 / 073$ & 0/098 & $-0 / 597$ & $0 / 196$ \\
\hline AC.Mixed.authentic.marketing & 618 & $0 / 201$ & 0/098 & $-0 / 537$ & $0 / 196$ \\
\hline AD.Authentic.values & 618 & $-0 / 088$ & 0/098 & $-0 / 375$ & $0 / 196$ \\
\hline BA.Practical & 618 & $0 / 128$ & 0/098 & $-0 / 572$ & $0 / 196$ \\
\hline BB.Problem.oriented & 618 & $-0 / 481$ & 0/098 & $-0 / 117$ & $0 / 196$ \\
\hline BC.Evolutionary.Product & 618 & $-0 / 657$ & 0/098 & $0 / 725$ & $0 / 196$ \\
\hline BD.Strategic.management.process.of.pragmatic.marketing & 618 & $-0 / 465$ & 0/098 & $-0 / 043$ & $0 / 196$ \\
\hline CA.Epistemology.shift & 618 & $-0 / 798$ & 0/098 & $0 / 212$ & $0 / 196$ \\
\hline CB.Ontology.shift & 618 & $-1 / 258$ & 0/098 & $2 / 056$ & $0 / 196$ \\
\hline CC.consumer.Growth & 618 & $0 / 221$ & 0/098 & $-0 / 546$ & $0 / 196$ \\
\hline CD.Out.of.structure.changes & 618 & $-0 / 27$ & 0/098 & $-0 / 507$ & $0 / 196$ \\
\hline Valid N (listwise) & 618 & & & & \\
\hline
\end{tabular}


INDEPENDENT JOURNAL OF MANAGEMENT \& PRODUCTION (IJM\&P)

http://www.ijmp.jor.br

v. 11, n. 6, September - October 2020

ISSN: 2236-269X

DOI: 10.14807/ijmp.v11i6.1151

\begin{tabular}{|c|c|}
\hline & 1-SSE/SSO \\
\hline A.Authentic.marketing & $0 / 523936$ \\
\hline AA.Paradigm.of.authentic.marketing & $0 / 30778$ \\
\hline AB.Making.social.platforms & $0 / 298232$ \\
\hline AC.Mixed.authentic.marketing & $0 / 699001$ \\
\hline AD.Authentic.values & $0 / 629964$ \\
\hline B.Pragmatic.marketing & $0 / 615912$ \\
\hline BA.Practical & $0 / 517945$ \\
\hline BB.Problem.oriented & $0 / 687462$ \\
\hline BC.Evolutionary.Product & $0 / 529344$ \\
\hline C.Paradigmatic.shift & $0 / 694588$ \\
\hline CA.Epistemology.shift & $0 / 298364$ \\
\hline CB.Ontology.shift & $0 / 396259$ \\
\hline CC.consumer.Growth & $0 / 50051$ \\
\hline CD.Out.of.structure.changes & $0 / 603307$ \\
\hline D.Authentic.Brand & $0 / 62704$ \\
\hline
\end{tabular}

\begin{tabular}{|c|c|}
\hline & 1-SSE/SSO \\
\hline AA.Paradigm.of.authentic.marketing & $0 / 693312$ \\
\hline AB.Making.social.platforms & $0 / 62123$ \\
\hline AC.Mixed.authentic.marketing & $0 / 801955$ \\
\hline AD.Authentic.values & $0 / 747614$ \\
\hline BA.Practical & $0 / 792707$ \\
\hline BB.Problem.oriented & $0 / 845949$ \\
\hline BC.Evolutionary.Product & $0 / 718134$ \\
\hline CA.Epistemology.shift & $0 / 825698$ \\
\hline CB.Ontology.shift & $0 / 140369$ \\
\hline CC.consumer.Growth & $0 / 441413$ \\
\hline CD.Out.of.structure.changes & $0 / 323265$ \\
\hline D.Authentic.Brand & $0 / 365367$ \\
\hline
\end{tabular}

\begin{tabular}{|c|c|}
\hline & 1-SSE/SSO \\
\hline A.Authentic.marketing & $0 / 449643$ \\
\hline AA.Paradigm.of.authentic.marketing & $0 / 380103$ \\
\hline AB.Making.social.platforms & $0 / 24399$ \\
\hline AC.Mixed.authentic.marketing & $0 / 574251$ \\
\hline AD.Authentic.values & $0 / 478237$ \\
\hline B.Pragmatic.marketing & $0 / 544509$ \\
\hline BA.Practical & $0 / 348354$ \\
\hline BB.Problem.oriented & $0 / 648757$ \\
\hline BC.Evolutionary.Product & $0 / 44114$ \\
\hline C.Paradigmatic.shift & $0 / 613797$ \\
\hline CA.Epistemology.shift & $0 / 451046$ \\
\hline CB.Ontology.shift & $0 / 371649$ \\
\hline CC.consumer.Growth & $0 / 642325$ \\
\hline CD.Out.of.structure.changes & $0 / 487116$ \\
\hline D.Authentic.Brand & $0 / 468669$ \\
\hline
\end{tabular}

\begin{tabular}{|c|c|}
\hline & 1-SSE/SSO \\
\hline AA.Paradigm.of.authentic.marketing & $0 / 377527$ \\
\hline AB.Making.social.platforms & $0 / 255201$ \\
\hline AC.Mixed.authentic.marketing & $0 / 571548$ \\
\hline AD.Authentic.values & $0 / 478209$ \\
\hline BA.Practical & $0 / 345724$ \\
\hline BB.Problem.oriented & $0 / 647787$ \\
\hline BC.Evolutionary.Product & $0 / 427883$ \\
\hline CA.Epistemology.shift & $0 / 61474$ \\
\hline CB.Ontology.shift & $0 / 371489$ \\
\hline CC.consumer.Growth & $0 / 641598$ \\
\hline CD.Out.of.structure.changes & $0 / 487504$ \\
\hline D.Authentic.Brand & $0 / 465636$ \\
\hline
\end{tabular}


INDEPENDENT JOURNAL OF MANAGEMENT \& PRODUCTION (IJM\&P)

http://www.ijmp.jor.br

v. 11, n. 6, September - October 2020

ISSN: 2236-269X

DOI: 10.14807/ijmp.v11i6.1151

\begin{tabular}{|c|c|c|c|c|c|}
\hline & $\begin{array}{c}\text { Original } \\
\text { Sample } \\
\text { (O) }\end{array}$ & $\begin{array}{l}\text { Sample } \\
\text { Mean } \\
\text { (M) }\end{array}$ & $\begin{array}{l}\text { Standard } \\
\text { Deviation } \\
\text { (STDEV) }\end{array}$ & $\begin{array}{l}\text { Standard } \\
\text { Error } \\
\text { (STERR) }\end{array}$ & $\begin{array}{l}\text { T Statistics } \\
(\mid \text { O/STERR } \mid)\end{array}$ \\
\hline AA1 <- AA.Paradigm.of.authentic.marketing & $0 / 804339$ & $0 / 804767$ & $0 / 02$ & $0 / 02$ & $40 / 815877$ \\
\hline AA1 <- A.Authentic.marketing & $0 / 501311$ & $0 / 500745$ & $0 / 037$ & $0 / 037$ & $13 / 489169$ \\
\hline AA2 <- AA.Paradigm.of.authentic.marketing & $0 / 824816$ & $0 / 823376$ & $0 / 018$ & $0 / 018$ & $46 / 862896$ \\
\hline AA2 <- A.Authentic.marketing & $0 / 538747$ & $0 / 534958$ & $0 / 036$ & $0 / 036$ & $14 / 921467$ \\
\hline AA3 <- AA.Paradigm.of.authentic.marketing & $0 / 867005$ & $0 / 86684$ & $0 / 013$ & $0 / 013$ & $68 / 901969$ \\
\hline AA3 <- A.Authentic.marketing & $0 / 620313$ & $0 / 618852$ & $0 / 036$ & $0 / 036$ & $17 / 455669$ \\
\hline AB1 <- AB.Making.social.platforms & $0 / 862637$ & $0 / 863611$ & $0 / 01$ & $0 / 01$ & 82/899968 \\
\hline AB1 <- A.Authentic.marketing & 0/763153 & $0 / 763006$ & $0 / 019$ & $0 / 019$ & $39 / 494436$ \\
\hline AB2 <- AB.Making.social.platforms & 0/68935 & $0 / 687123$ & $0 / 041$ & $0 / 041$ & 16/646562 \\
\hline AB3 <- AB.Making.social.platforms & $0 / 780914$ & $0 / 779353$ & $0 / 027$ & $0 / 027$ & $29 / 175994$ \\
\hline AB3 <- A.Authentic.marketing & 0/513709 & $0 / 514185$ & $0 / 043$ & $0 / 043$ & $11 / 943296$ \\
\hline AC1 <- AC.Mixed.authentic.marketing & $0 / 863771$ & $0 / 863411$ & $0 / 013$ & $0 / 013$ & $65 / 551229$ \\
\hline AC1 <- A.Authentic.marketing & 0/799713 & $0 / 799935$ & $0 / 018$ & $0 / 018$ & 45/689055 \\
\hline AC2 <- AC.Mixed.authentic.marketing & $0 / 932504$ & $0 / 932399$ & $0 / 007$ & $0 / 007$ & $140 / 284086$ \\
\hline AC2 <- A.Authentic.marketing & $0 / 858334$ & $0 / 858285$ & $0 / 013$ & $0 / 013$ & $66 / 207558$ \\
\hline AC3 <- AC.Mixed.authentic.marketing & $0 / 890458$ & $0 / 890573$ & $0 / 012$ & $0 / 012$ & $77 / 397274$ \\
\hline AC3 <- A.Authentic.marketing & $0 / 849271$ & $0 / 849183$ & $0 / 013$ & $0 / 013$ & $66 / 481346$ \\
\hline AD1 <- AD.Authentic.values & $0 / 911452$ & 0/911741 & $0 / 007$ & $0 / 007$ & $123 / 5163$ \\
\hline AD1 <- A.Authentic.marketing & $0 / 878778$ & 0/87929 & $0 / 009$ & $0 / 009$ & 93/129102 \\
\hline AD2 <- AD.Authentic.values & $0 / 841816$ & $0 / 841854$ & $0 / 016$ & $0 / 016$ & $52 / 270953$ \\
\hline AD2 <- A.Authentic.marketing & $0 / 76353$ & $0 / 763127$ & $0 / 021$ & $0 / 021$ & $37 / 110093$ \\
\hline AD3 <- AD.Authentic.values & $0 / 839052$ & $0 / 839622$ & $0 / 016$ & $0 / 016$ & $51 / 495223$ \\
\hline AD3 <- A.Authentic.marketing & $0 / 73343$ & $0 / 734113$ & $0 / 022$ & $0 / 022$ & $33 / 215581$ \\
\hline BA1 <- BA.Practical & $0 / 872463$ & $0 / 872215$ & $0 / 013$ & $0 / 013$ & $66 / 908708$ \\
\hline BA1 <- B.Pragmatic.marketing & $0 / 658428$ & $0 / 658746$ & $0 / 026$ & $0 / 026$ & $25 / 378864$ \\
\hline BA2 <- BA.Practical & 0/910635 & $0 / 910564$ & $0 / 007$ & $0 / 007$ & $131 / 813824$ \\
\hline BA2 <- B.Pragmatic.marketing & $0 / 778681$ & $0 / 778178$ & $0 / 017$ & $0 / 017$ & $45 / 240017$ \\
\hline BB1 <- BB.Problem.oriented & $0 / 932371$ & $0 / 932389$ & $0 / 007$ & $0 / 007$ & $135 / 892547$ \\
\hline BB1 <- B.Pragmatic.marketing & $0 / 8265$ & $0 / 826749$ & $0 / 015$ & $0 / 015$ & $56 / 391314$ \\
\hline BB2 <- BB.Problem.oriented & $0 / 909278$ & $0 / 908676$ & $0 / 011$ & $0 / 011$ & $85 / 938388$ \\
\hline BB2 <- B.Pragmatic.marketing & $0 / 82521$ & $0 / 824325$ & $0 / 015$ & $0 / 015$ & $53 / 591254$ \\
\hline BB3 <- BB.Problem.oriented & $0 / 91754$ & $0 / 917297$ & $0 / 009$ & $0 / 009$ & $103 / 824262$ \\
\hline BB3 <- B.Pragmatic.marketing & $0 / 83581$ & $0 / 835723$ & $0 / 015$ & $0 / 015$ & $56 / 25353$ \\
\hline BC1 <- BC.Evolutionary.Product & $0 / 906314$ & $0 / 906054$ & $0 / 009$ & $0 / 009$ & $106 / 364066$ \\
\hline BC1 <- B.Pragmatic.marketing & 0/783175 & $0 / 782875$ & $0 / 019$ & $0 / 019$ & $40 / 208566$ \\
\hline BC2 <- BC.Evolutionary.Product & $0 / 90424$ & $0 / 904307$ & $0 / 009$ & $0 / 009$ & 100/812573 \\
\hline BC2 <- B.Pragmatic.marketing & 0/775252 & 0/774951 & $0 / 02$ & $0 / 02$ & $39 / 468098$ \\
\hline BC3 <- BC.Evolutionary.Product & $0 / 720885$ & $0 / 719324$ & $0 / 032$ & $0 / 032$ & $22 / 856282$ \\
\hline BC3 <- B.Pragmatic.marketing & 0/611381 & $0 / 610897$ & $0 / 033$ & $0 / 033$ & 18/387129 \\
\hline $\begin{array}{l}\text { BD1 <- } \\
\text { BD.Strategic.management.process.of.pragmatic.marketing }\end{array}$ & 0/889993 & 0/890041 & $0 / 01$ & $0 / 01$ & $92 / 296428$ \\
\hline BD1 <- B.Pragmatic.marketing & $0 / 830916$ & $0 / 831346$ & $0 / 015$ & $0 / 015$ & $56 / 158446$ \\
\hline $\begin{array}{c}\text { BD2 }<- \\
\text { BD.Strategic.management.process.of.pragmatic.marketing }\end{array}$ & 0/910449 & 0/910548 & $0 / 01$ & $0 / 01$ & 93/647935 \\
\hline BD2 <- B.Pragmatic.marketing & $0 / 822512$ & $0 / 822924$ & $0 / 017$ & $0 / 017$ & $49 / 152509$ \\
\hline $\begin{array}{c}\text { BD3 }<- \\
\text { BD.Strategic.management.process.of.pragmatic.marketing }\end{array}$ & 0/925321 & 0/924736 & $0 / 009$ & $0 / 009$ & 103/484707 \\
\hline BD3 <- B.Pragmatic.marketing & $0 / 846919$ & $0 / 846742$ & $0 / 014$ & $0 / 014$ & $59 / 722481$ \\
\hline CA1 <- CA.Epistemology.shift & 0/911186 & $0 / 911182$ & $0 / 009$ & $0 / 009$ & $102 / 356431$ \\
\hline CA1 <- C.Paradigmatic.shift & 0/650899 & $0 / 649068$ & $0 / 029$ & $0 / 029$ & $22 / 5566$ \\
\hline CA2 <- CA.Epistemology.shift & $0 / 885283$ & $0 / 884623$ & $0 / 013$ & $0 / 013$ & 66/319481 \\
\hline CA2 <- C.Paradigmatic.shift & $0 / 57664$ & $0 / 574433$ & $0 / 034$ & $0 / 034$ & $16 / 88849$ \\
\hline CB1 <- CB.Ontology.shift & $0 / 882678$ & $0 / 881409$ & $0 / 015$ & $0 / 015$ & 59/34499 \\
\hline CB1 <- C.Paradigmatic.shift & 0/73631 & $0 / 734203$ & $0 / 023$ & $0 / 023$ & $31 / 626648$ \\
\hline CB2 <- CB.Ontology.shift & $0 / 930283$ & 0/930116 & $0 / 009$ & $0 / 009$ & 99/662915 \\
\hline CB2 <- C.Paradigmatic.shift & $0 / 724125$ & $0 / 723149$ & $0 / 025$ & $0 / 025$ & 28/761617 \\
\hline CB3 <- CB.Ontology.shift & $0 / 939025$ & $0 / 938875$ & $0 / 008$ & $0 / 008$ & $116 / 700002$ \\
\hline CB3 <- C.Paradigmatic.shift & $0 / 721426$ & 0/72075 & $0 / 024$ & $0 / 024$ & $30 / 010614$ \\
\hline CC1 <- CC.consumer.Growth & $0 / 871945$ & $0 / 871616$ & $0 / 01$ & $0 / 01$ & $85 / 972517$ \\
\hline CC1 <- C.Paradigmatic.shift & 0/788951 & 0/788196 & $0 / 015$ & $0 / 015$ & $51 / 002681$ \\
\hline CC2 <- CC.consumer.Growth & $0 / 841441$ & $0 / 842032$ & $0 / 016$ & $0 / 016$ & $53 / 715421$ \\
\hline CC2 <- C.Paradigmatic.shift & 0/751156 & 0/752009 & $0 / 019$ & $0 / 019$ & 38/534551 \\
\hline CC3 <- CC.consumer.Growth & $0 / 892036$ & 0/89171 & $0 / 009$ & $0 / 009$ & 95/050533 \\
\hline CC3 <- C.Paradigmatic.shift & 0/757364 & 0/756921 & $0 / 016$ & $0 / 016$ & 48/095293 \\
\hline CD1 <- CD.Out.of.structure.changes & $0 / 853321$ & $0 / 852446$ & $0 / 014$ & $0 / 014$ & $62 / 583618$ \\
\hline
\end{tabular}


INDEPENDENT JOURNAL OF MANAGEMENT \& PRODUCTION (IJM\&P)

http://www.ijmp.jor.br

v. 11, n. 6, September - October 2020

ISSN: 2236-269X

DOI: 10.14807/ijmp.v11i6.1151

CD1 <- C.Paradigmatic.shift

CD2 <- CD.Out.of.structure.changes

CD2 <- C.Paradigmatic.shift

CD3 <- CD.Out.of.structure.changes

CD3 <- C.Paradigmatic.shift

D1 <- D.Authentic.Brand

D2 <- D.Authentic.Brand

D3 <- D.Authentic.Brand

\begin{tabular}{c|c|c|c|c|}
$0 / 793515$ & $0 / 792778$ & $0 / 017$ & $0 / 017$ & $47 / 476377$ \\
\hline $0 / 904459$ & $0 / 904381$ & $0 / 008$ & $0 / 008$ & $119 / 499772$ \\
\hline $0 / 832185$ & $0 / 832509$ & $0 / 012$ & $0 / 012$ & $67 / 327133$ \\
\hline $0 / 825891$ & $0 / 825129$ & $0 / 019$ & $0 / 019$ & $42 / 65524$ \\
\hline $0 / 758575$ & $0 / 758648$ & $0 / 022$ & $0 / 022$ & $34 / 546718$ \\
\hline $0 / 893323$ & $0 / 893305$ & $0 / 008$ & $0 / 008$ & $111 / 836571$ \\
\hline $0 / 8972$ & $0 / 89716$ & $0 / 009$ & $0 / 009$ & $96 / 343665$ \\
\hline $0 / 738535$ & $0 / 738116$ & $0 / 026$ & $0 / 026$ & $28 / 126542$ \\
\hline
\end{tabular}

\begin{tabular}{|c|c|c|c|c|c|}
\hline & $\begin{array}{c}\text { Original } \\
\text { Sample } \\
\text { (O) }\end{array}$ & $\begin{array}{l}\text { Sample } \\
\text { Mean } \\
\text { (M) }\end{array}$ & $\begin{array}{l}\text { Standard } \\
\text { Deviation } \\
\text { (STDEV) }\end{array}$ & $\begin{array}{l}\text { Standard } \\
\text { Error } \\
\text { (STERR) }\end{array}$ & $\begin{array}{l}\text { T Statistics } \\
(\mid \mathbf{O} / \text { STERR } \mid)\end{array}$ \\
\hline AA1 <- AA.Paradigm.of.authentic.marketing & $0 / 819771$ & $0 / 820412$ & $0 / 020555$ & $0 / 020555$ & 39/88231 \\
\hline AA2 <- AA.Paradigm.of.authentic.marketing & $0 / 837101$ & $0 / 836757$ & $0 / 016758$ & $0 / 016758$ & 49/951534 \\
\hline AA3 <- AA.Paradigm.of.authentic.marketing & $0 / 841072$ & $0 / 840426$ & $0 / 020764$ & $0 / 020764$ & $40 / 506618$ \\
\hline AB1 <- AB.Making.social.platforms & $0 / 81481$ & $0 / 814414$ & $0 / 02026$ & $0 / 02026$ & $40 / 218343$ \\
\hline AB2 <- AB.Making.social.platforms & $0 / 733072$ & $0 / 733603$ & $0 / 037253$ & $0 / 037253$ & $19 / 678272$ \\
\hline AB3 <- AB.Making.social.platforms & $0 / 814511$ & $0 / 813766$ & $0 / 021841$ & $0 / 021841$ & $37 / 292133$ \\
\hline AC1 <- AC.Mixed.authentic.marketing & $0 / 882901$ & $0 / 882269$ & $0 / 010912$ & $0 / 010912$ & $80 / 908207$ \\
\hline AC2 <- AC.Mixed.authentic.marketing & $0 / 930973$ & $0 / 931202$ & $0 / 006665$ & $0 / 006665$ & 139/678848 \\
\hline AC3 <- AC.Mixed.authentic.marketing & $0 / 87153$ & $0 / 870619$ & $0 / 017173$ & $0 / 017173$ & $50 / 749431$ \\
\hline AD1 <- AD.Authentic.values & $0 / 910916$ & $0 / 910917$ & $0 / 008052$ & $0 / 008052$ & $113 / 124359$ \\
\hline AD2 <- AD.Authentic.values & $0 / 849463$ & $0 / 848514$ & $0 / 017306$ & $0 / 017306$ & $49 / 085759$ \\
\hline AD3 <- AD.Authentic.values & $0 / 831383$ & $0 / 831273$ & $0 / 019565$ & $0 / 019565$ & $42 / 49298$ \\
\hline BA1 <- BA.Practical & $0 / 854861$ & $0 / 853424$ & $0 / 019072$ & $0 / 019072$ & $44 / 82183$ \\
\hline BA2 <- BA.Practical & $0 / 924512$ & $0 / 924666$ & $0 / 007036$ & $0 / 007036$ & $131 / 404682$ \\
\hline BB1 <- BB.Problem.oriented & $0 / 930728$ & $0 / 930488$ & $0 / 007418$ & $0 / 007418$ & $125 / 463311$ \\
\hline BB2 <- BB.Problem.oriented & $0 / 909307$ & $0 / 908483$ & $0 / 010705$ & $0 / 010705$ & $84 / 942277$ \\
\hline BB3 <- BB.Problem.oriented & $0 / 9191$ & $0 / 918354$ & $0 / 008799$ & $0 / 008799$ & $104 / 451454$ \\
\hline BC1 <- BC.Evolutionary.Product & $0 / 890931$ & $0 / 890467$ & $0 / 011315$ & $0 / 011315$ & 78/736042 \\
\hline BC2 <- BC.Evolutionary.Product & $0 / 887281$ & $0 / 88651$ & $0 / 012887$ & $0 / 012887$ & $68 / 851365$ \\
\hline BC3 <- BC.Evolutionary.Product & $0 / 757586$ & $0 / 757024$ & $0 / 023984$ & $0 / 023984$ & $31 / 586801$ \\
\hline $\begin{array}{c}\text { BD1 <- } \\
\text { BD.Strategic.management.process.of.pragmatic.marketing }\end{array}$ & 0/881734 & 0/881301 & $0 / 011164$ & 0/011164 & 78/979857 \\
\hline $\begin{array}{c}\text { BD2 }<- \\
\text { BD.Strategic.management.process.of.pragmatic.marketing }\end{array}$ & 0/915464 & 0/915384 & 0/008972 & 0/008972 & $102 / 040945$ \\
\hline $\begin{array}{c}\text { BD3 }<- \\
\text { BD.Strategic.management.process.of.pragmatic.marketing }\end{array}$ & 0/928123 & 0/927859 & 0/008523 & $0 / 008523$ & 108/890539 \\
\hline CA1 <- CA.Epistemology.shift & $0 / 913501$ & $0 / 912995$ & $0 / 010197$ & 0/010197 & $89 / 582509$ \\
\hline CA2 <- CA.Epistemology.shift & $0 / 882639$ & $0 / 883157$ & $0 / 015698$ & $0 / 015698$ & $56 / 227552$ \\
\hline CB1 <- CB.Ontology.shift & $0 / 884279$ & $0 / 883629$ & $0 / 015143$ & $0 / 015143$ & $58 / 396739$ \\
\hline CB2 <- CB.Ontology.shift & $0 / 930208$ & $0 / 930226$ & $0 / 009213$ & $0 / 009213$ & $100 / 968358$ \\
\hline CB3 <- CB.Ontology.shift & $0 / 937436$ & $0 / 937701$ & $0 / 008931$ & $0 / 008931$ & $104 / 961002$ \\
\hline CC1 <- CC.consumer.Growth & $0 / 864512$ & $0 / 864729$ & $0 / 011245$ & $0 / 011245$ & $76 / 88027$ \\
\hline CC2 <- CC.consumer.Growth & $0 / 843455$ & $0 / 843248$ & $0 / 016337$ & $0 / 016337$ & $51 / 627378$ \\
\hline CC3 <- CC.consumer.Growth & $0 / 897425$ & $0 / 897759$ & $0 / 009178$ & $0 / 009178$ & $97 / 777169$ \\
\hline CD1 <- CD.Out.of.structure.changes & $0 / 83239$ & $0 / 833144$ & $0 / 01686$ & $0 / 01686$ & $49 / 370004$ \\
\hline CD2 <- CD.Out.of.structure.changes & $0 / 902899$ & $0 / 903321$ & $0 / 00765$ & $0 / 00765$ & $118 / 033622$ \\
\hline CD3 <- CD.Out.of.structure.changes & $0 / 847023$ & $0 / 847134$ & $0 / 014354$ & $0 / 014354$ & $59 / 009862$ \\
\hline D1 <- D.Authentic.Brand & $0 / 887772$ & $0 / 88805$ & $0 / 008871$ & $0 / 008871$ & $100 / 071915$ \\
\hline D2 <- D.Authentic.Brand & $0 / 895059$ & $0 / 895134$ & $0 / 009376$ & $0 / 009376$ & $95 / 463396$ \\
\hline D3 <- D.Authentic.Brand & $0 / 7505$ & $0 / 750747$ & $0 / 024639$ & $0 / 024639$ & $30 / 459628$ \\
\hline
\end{tabular}

\begin{tabular}{|c|c|}
\hline & Cronbachs Alpha \\
\hline A.Authentic.marketing & $0 / 903279$ \\
\hline AA.Paradigm.of.authentic.marketing & $0 / 778997$ \\
\hline AB.Making.social.platforms & $0 / 703505$ \\
\hline AC.Mixed.authentic.marketing & $0 / 876689$ \\
\hline AD.Authentic.values & $0 / 83091$ \\
\hline B.Pragmatic.marketing & $0 / 936299$ \\
\hline BA.Practical & $0 / 744165$ \\
\hline BB.Problem.oriented & $0 / 908917$ \\
\hline BC.Evolutionary.Product & $0 / 800207$ \\
\hline C.Paradigmatic.shift & $0 / 894337$ \\
\hline CA.Epistemology.shift & $0 / 915435$ \\
\hline CB.Ontology.shift & $0 / 761654$ \\
\hline
\end{tabular}


INDEPENDENT JOURNAL OF MANAGEMENT \& PRODUCTION (IJM\&P)

http://www.ijmp.jor.br

v. 11, n. 6, September - October 2020

ISSN: 2236-269X

DOI: 10.14807/ijmp.v11i6.1151

CC.consumer.Growth

CD.Out.of.structure.changes

D.Authentic.Brand

$0 / 837141$

$0 / 826032$

$0 / 803806$

A.Authentic.marketing

AA.Paradigm.of.authentic.marketing

AB.Making.social.platforms

AC.Mixed.authentic.marketing

AD.Authentic.values

B.Pragmatic.marketing

BA.Practical

BB.Problem.oriented

BC.Evolutionary.Product

BD.Strategic.management.process.of.pragmatic.marketing

C.Paradigmatic.shift

CA.Epistemology.shift

CB.Ontology.shift

CC.consumer.Growth

CD.Out.of.structure.changes

D.Authentic.Brand

AVE

0/52394

$0 / 692993$

$0 / 609724$

$0 / 80286$

$0 / 747803$

$0 / 615901$

$0 / 795223$

$0 / 845993$

$0 / 719577$

$0 / 825741$

$0 / 545551$

$0 / 806993$

$0 / 842105$

$0 / 75468$

$0 / 742766$

$0 / 716142$

A.Authentic.marketing

AA.Paradigm.of.authentic.marketing

AB.Making.social.platforms

AC.Mixed.authentic.marketing

AD.Authentic.values

B.Pragmatic.marketing

BA.Practical

BB.Problem.oriented

BC.Evolutionary.Product

BD.Strategic.management.process.of.pragmatic.marketing

C.Paradigmatic.shift

CA.Epistemology.shift

CB.Ontology.shift

CC.consumer.Growth

CD.Out.of.structure.changes

D.Authentic.Brand

Composite Reliability

0/921127

$0 / 871219$

$0 / 822957$

$0 / 924274$

$0 / 898807$

$0 / 945898$

$0 / 885886$

$0 / 942785$

$0 / 883954$

$0 / 934263$

$0 / 929058$

$0 / 893169$

$0 / 941136$

0/902187

$0 / 896375$

$0 / 882505$

A.Authentic.marketing

AA.Paradigm.of.authentic.marketing

AB.Making.social.platforms

AC.Mixed.authentic.marketing

AD.Authentic.values

B.Pragmatic.marketing

BA.Practical

BB.Problem.oriented

BC.Evolutionary.Product

BD.Strategic.management.process.of.pragmatic.marketing

C.Paradigmatic.shift

CA.Epistemology.shift

CB.Ontology.shift

CC.consumer.Growth

CD.Out.of.structure.changes

D.Authentic.Brand

communality

$0 / 52394$

$0 / 692993$

$0 / 609723$

$0 / 80286$

$0 / 747803$

$0 / 615901$

$0 / 795223$

$0 / 845993$

$0 / 719577$

$0 / 825741$

$0 / 545551$

$0 / 806993$

$0 / 842105$

$0 / 75468$

$0 / 742766$

$0 / 716142$

A.Authentic.marketing

AA.Paradigm.of.authentic.marketing

R Square

AB.Making.social.platforms

AC.Mixed.authentic.marketing

AD.Authentic.values

B.Pragmatic.marketing

$0 / 44709$

$0 / 54959$

$0 / 871077$

$0 / 845305$ 
INDEPENDENT JOURNAL OF MANAGEMENT \& PRODUCTION (IJM\&P)

http://www.ijmp.jor.br

v. 11, n. 6, September - October 2020

ISSN: 2236-269X

DOI: 10.14807/ijmp.v11i6.1151

\begin{tabular}{|c|c|}
\hline BA.Practical & $0 / 65635$ \\
\hline BB.Problem.oriented & $0 / 812833$ \\
\hline BC.Evolutionary.Product & $0 / 735732$ \\
\hline BD.Strategic.management.process.of.pragmatic.marketing & $0 / 841504$ \\
\hline C.Paradigmatic.shift & $0 / 55076$ \\
\hline CA.Epistemology.shift & $0 / 469512$ \\
\hline CB.Ontology.shift & $0 / 628984$ \\
\hline CC.consumer.Growth & $0 / 778087$ \\
\hline CD.Out.of.structure.changes & $0 / 851632$ \\
\hline D.Authentic.Brand & $0 / 589519$ \\
\hline
\end{tabular}

\begin{tabular}{|c|c|}
\hline & Cronbachs Alpha \\
\hline AA.Paradigm.of.authentic.marketing & $0 / 778997$ \\
\hline AB.Making.social.platforms & $0 / 703505$ \\
\hline AC.Mixed.authentic.marketing & $0 / 876689$ \\
\hline AD.Authentic.values & $0 / 83091$ \\
\hline BA.Practical & $0 / 744165$ \\
\hline BB.Problem.oriented & $0 / 908917$ \\
\hline BC.Evolutionary.Product & $0 / 800207$ \\
\hline CA.Epistemology.shift & $0 / 894337$ \\
\hline CB.Ontology.shift & $0 / 761654$ \\
\hline CC.consumer.Growth & $0 / 905823$ \\
\hline CD.Out.of.structure.changes & $0 / 837141$ \\
\hline D.Authentic.Brand & $0 / 826032$ \\
\hline
\end{tabular}

\begin{tabular}{|c|c|}
\hline & AVE \\
\hline AA.Paradigm.of.authentic.marketing & $0 / 693388$ \\
\hline AB.Making.social.platforms & $0 / 62158$ \\
\hline AC.Mixed.authentic.marketing & $0 / 80193$ \\
\hline AD.Authentic.values & $0 / 747518$ \\
\hline BA.Practical & $0 / 792755$ \\
\hline BB.Problem.oriented & $0 / 845946$ \\
\hline BC.Evolutionary.Product & $0 / 718321$ \\
\hline CA.Epistemology.shift & $0 / 825647$ \\
\hline CB.Ontology.shift & $0 / 806768$ \\
\hline CC.consumer.Growth & $0 / 842008$ \\
\hline CD.Out.of.structure.changes & $0 / 754722$ \\
\hline D.Authentic.Brand & $0 / 741849$ \\
\hline
\end{tabular}

\begin{tabular}{|c|c|}
\hline & Composite Reliability \\
\hline AA.Paradigm.of.authentic.marketing & $0 / 871524$ \\
\hline AB.Making.social.platforms & $0 / 830966$ \\
\hline AC.Mixed.authentic.marketing & $0 / 923874$ \\
\hline AD.Authentic.values & $0 / 898665$ \\
\hline BA.Practical & $0 / 884242$ \\
\hline BB.Problem.oriented & $0 / 942766$ \\
\hline BC.Evolutionary.Product & $0 / 883849$ \\
\hline CA.Epistemology.shift & $0 / 93421$ \\
\hline CB.Ontology.shift & $0 / 893023$ \\
\hline CC.consumer.Growth & $0 / 941099$ \\
\hline CD.Out.of.structure.changes & $0 / 9022$ \\
\hline D.Authentic.Brand & $0 / 895946$ \\
\hline
\end{tabular}

\begin{tabular}{|c|c|}
\hline & communality \\
\hline AA.Paradigm.of.authentic.marketing & $0 / 693388$ \\
\hline AB.Making.social.platforms & $0 / 621579$ \\
\hline AC.Mixed.authentic.marketing & $0 / 80193$ \\
\hline AD.Authentic.values & $0 / 747518$ \\
\hline BA.Practical & $0 / 792755$ \\
\hline BB.Problem.oriented & $0 / 845946$ \\
\hline BC.Evolutionary.Product & $0 / 718321$ \\
\hline BD.Strategic.management.process.of.pragmatic.marketing & $0 / 825647$ \\
\hline
\end{tabular}


http://www.ijmp.jor.br

v. 11, n. 6, September - October 2020

ISSN: 2236-269X

DOI: 10.14807/ijmp.v11i6.1151

\begin{tabular}{|c|c|}
\hline CA.Epistemology.shift & $0 / 806768$ \\
\hline CB.Ontology.shift & $0 / 842008$ \\
\hline CC.consumer.Growth & $0 / 754722$ \\
\hline CD.Out.of.structure.changes & $0 / 741849$ \\
\hline D.Authentic.Brand & $0 / 717507$ \\
\hline
\end{tabular}

\begin{tabular}{|c|c|}
\hline \multicolumn{1}{|c|}{ R Square } \\
\hline AA.Paradigm.of.authentic.marketing & \\
\hline AB.Making.social.platforms & \\
\hline AC.Mixed.authentic.marketing & \\
\hline AD.Authentic.values & \\
\hline BA.Practical & \\
\hline BB.Problem.oriented & \\
\hline BC.Evolutionary.Product & \\
\hline CA.Epistemology.shift & $0 / 174067$ \\
\hline CB.Ontology.shift & $0 / 529458$ \\
\hline CC.consumer.Growth & $0 / 430638$ \\
\hline CD.Out.of.structure.changes & $0 / 500208$ \\
\hline D.Authentic.Brand & $0 / 657458$ \\
\hline
\end{tabular}

